Historic, Archive Document

Do not assume content reflects current scientific knowledge, policies, or practices. 



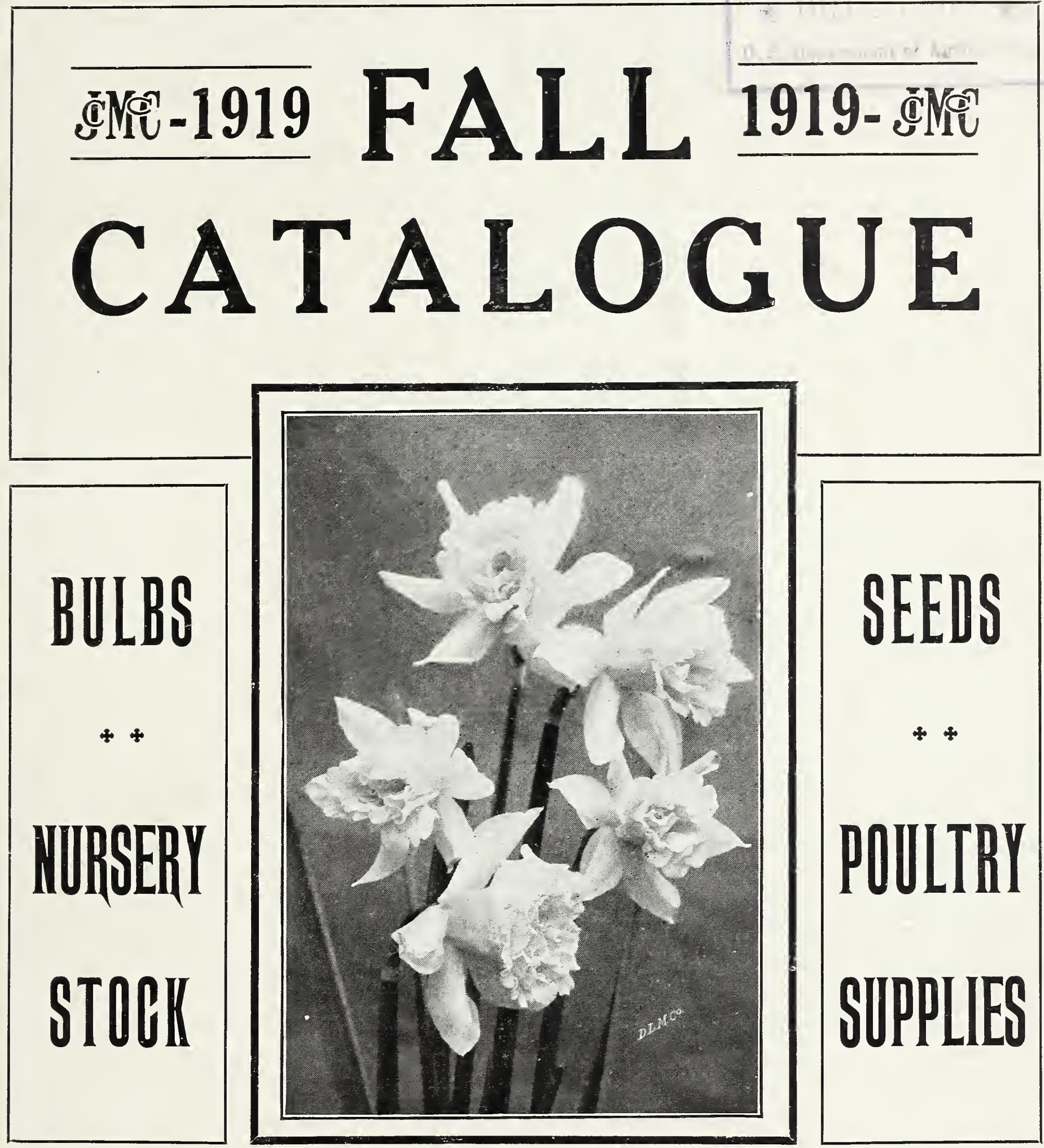

A MODERN SEED STORE

THE J. CHAS. McCULLOUGH SEED CO.

\begin{tabular}{llllllll}
$S$ & $E$ & $E$ & $D$ & $S$ & $M$ & $E$ & $N$ \\
\hline
\end{tabular}

228, 230 and 232 EAST FOURTH ST.

North Side, Between Main and Sycamore Streets 
BULBS AND ROOTS THAT WE WERE PROHIBITED 'TO IMPORT BY RULING OF UNITED STATES FEDERAL HORTIGUL'TURAL BOARD.

The United States Federal Horticultural Board, Washington, D. C., by an Embargo which went into force on June 1st, 1919, prohibits the importation of the following Blubs and Roots into the United States.

$\begin{array}{ll}\text { Allium Neapolitanum } & \text { Crown Imperial (Fritillaria) } \\ \text { Anemone } & \text { Anomatheca Cruenta (Scarlet Freesias) } \\ \text { Babiana } & \text { Gladioli (All varieties) } \\ \text { Chionodoxa } & \text { Irises, including Spanish, English } \\ \text { Dielytra } & \text { and Species } \\ \text { Dog's Tooth Violet (Erythronium) } & \text { Ixias }\end{array}$

\author{
Muscari (Grape Hyacinth) \\ Ornithogalum (Star of Bethlehem) \\ Oxalis \\ Ranunculus \\ Snowdrops \\ Scillas (All varieties) \\ Spireas, including Astilbes \\ Triteleia
}

\title{
TERMS AND INFORMATION.
}

\section{ALL PRIGES SUBJEGT TO GHANGE without notice.}

PRICES INCLUDE POSTAGE at sing?e and dozen rates, except where noted. At 100 and 1000 rates buyer payes charges. 6 bulbs sold at dozen rates, 25 at 100 rates, 250 at 1000 rates.

ON LARGE ORDERS. We will quote special prices. Write us

SCHOOL GARDENS. To encourage love of flowers and to aid in knowledge of care and growth of plants, we will furnish both Bulbs and Seeds at very low rates.

Principals and teachers are requested to write us outlining their needs.

REMITTANCES SHOULD ACCOMPANY ORDERS. C. O. D. shipments are not desired by us. Money orders are the best form of remittance, but stamps may be sent for small amounts.

SEND US NAMES and ADDRESSES of your friends for our catalogue when sending your order and we will send you a small collection of Flower Seeds.

SUBSTITUTION. We endeavor to fill all orders exactly as received, but it sometimes happens that some varieties of Named Hyacinths and other bulbs become exhausted, in which case we will, unless otherwise instructed, send a variety as near like it as possible.

INFORMATION FREE. Our 45 years active experience in the Seed Business in all its branches means that we know many things. We shall be always pleased to give information to customers on any subject pertaining to Seeds and Crops, such as best varieties, when, what and how to sow, culture and care of all crops, besides remedies for plant diseases, insect pests, fertilization and other matters, so far as in our power.

We invite personal relations and questions and extend you a cordial invitation to visit our Modern Store and Salesrooms, 228-230-232 E. 4th St., Gincinnati, Ohio.

We give no warranty, express or implied, as to description, quality, productiveness or any other matter of any seeds, bulbs, or plants we send out and we will not be in any way responsible for the crop.

THE J. GHas. McGullough SEed CO.

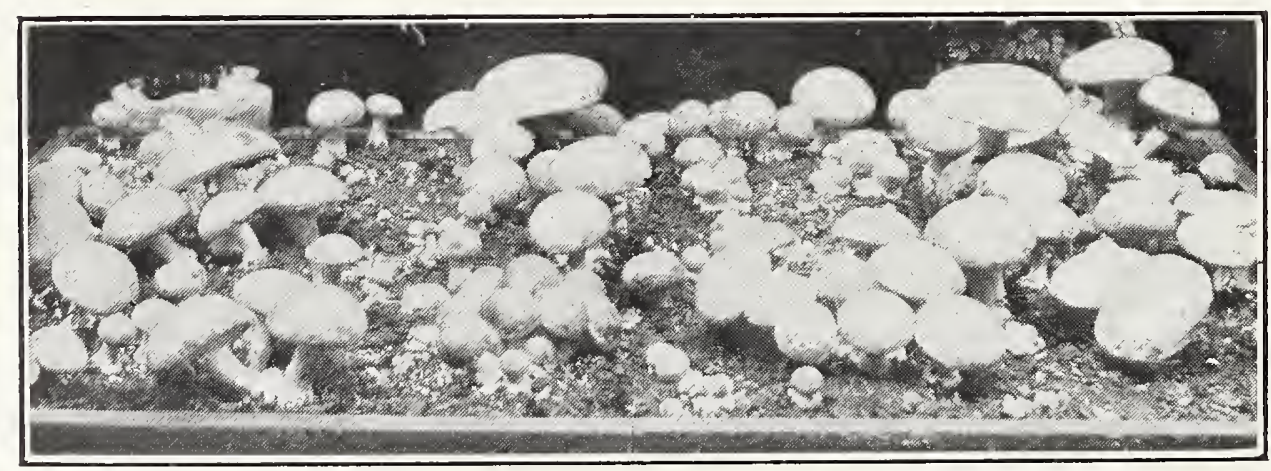

MUSHROOMS IN A BED

\section{MUSHROOM SPAWN.}

Mushrooms can be grown in cellars, sheds, under benches in green houses or hot beds. They are also planted outside in pastures or sod. It is a very profitable crop both for forcing or a field crop. Our cultural instructions are somewhat limited but we can furnish a booklet of more extended information on "How to Grow Mushrooms." Price, 10c.

One brick will spawn about ten feet square.

GULTURE-In preparing a mushroom bed, take three parts fresh stable manure, free from straw, and one part of good pasture soil. Mix thoroughly together and let it stand until the heat has sunk to about 90 degrces. Make the bed from this mixture about four feet wide, eight inches deep, and any desired length. As soon as the temperature of the bed is about 70 or 80 degrees, the spawn may be inserted in pieces about the size of a walnut, and six inches apart each way. When the spawn is diffused through the whole bed, which will be in about ten days from planting, cover with two inches of fine loam and press down firmly. Over this, place a layer of straw about four inches thick. Do not water unless the surface gets cxtremely dry, and then only with water at a temperature of 80 degrees. 7 hen gathering the crop, twist them off at the roots and do not use a knife. Cover the hole with soil to keep insects away from the root. Mushrooms can be grown in a great variety of situations; under the benches in a green house, a dark room, cellar, stable or eslewhere.

ENGLISH MUSHROOM SPAWN-Well known and popular. Put up in bricks weighing about $1 \frac{1}{4} \mathrm{lbs}$. Per brick, 25c; 5 bricks, $\$ \mathbf{1 . 0 0}$. 


\section{HYACINTHS}

Hyacinths are offered in four classes, viz:-

FIRST SIZE NAMED the most select exhibition Hyacinths producing very large spikes and the best for pots or glasses.

SECOND SIZE NAMED not quite so large but suitable for pots and the best for bedding, as there is more uniformity in height and more pleasing effects in color schemes.

UNNAMED or MIXED-For pots or bedding, made up of miscellaneous varieties.

MINIATURE, for planting in bulb pans or trays in masses fordecorative use in house or for cutting.

GROWING IN POTS-Use Select Named Sorts (single Varieties are best), one bulb to a four or five inch pot, three to a seven inch pot. Window boxes having good drainage can be used, placing the bulbs about 3 inches apart. Use any good, rich garden soil, or even spagnam moss with a little sheep manure will do. Plant any time from September to December, but early planting is best. potting, the top of the bulb should be $1 / 2$ inch below the top of the soil and the soil pressed firmly around the bulb but not packed underneath, as it restricts root growth. Then water thoroughly, setting away in a dark, cool place for six
until the roots have grown. Then bring to a warm room as many as desired to bloom at a time.

CULTURE IN GLASSES-To grow hyacinths in water select dark colored glass and place bulb so that the base merely touches the water. Set in a cool, dark place until roots have made a good growth, when they may be brought into the light. Give the plants the water. plenty of light and as much resh air as possible and entirely if it becomes impure; a small piece of charcoal put in the water will keep it pure much longer.

OUT OF DOORS-Hyacinths will succeed in any good garden soil, but best if rich and light, hence cow manure and sand added to heavy soils are beneficial. They can be planted from October until the ground freezes, but moderately early planting is best. Have the beds or borders well spaded, setting the bulbs five or six inches deep and the same distances apart. In covering do not press the soil too firmly around the bulb. On approach of winter a top dressing of leaf mould or well rotted manure is beneficial.

Color schemes for beds are best obtained by using Second Size Named Hyacinths rather than Mixed, as more regularity of height, bloom and shadings are obtained. However, our Choice Mixed or Unnamed Hyacinths are fine quality and will give excellent results.

\section{Select Named Hyacinths 1st Size}

\section{SINGLE VARIETIES.}

The best for pots, glasses, or in beds where large fine exhibition spikes are desired. Make much fuller, larger and more symmetrical spikes than the Double_Hyacinths. Prices include postage at single and dozen rates.

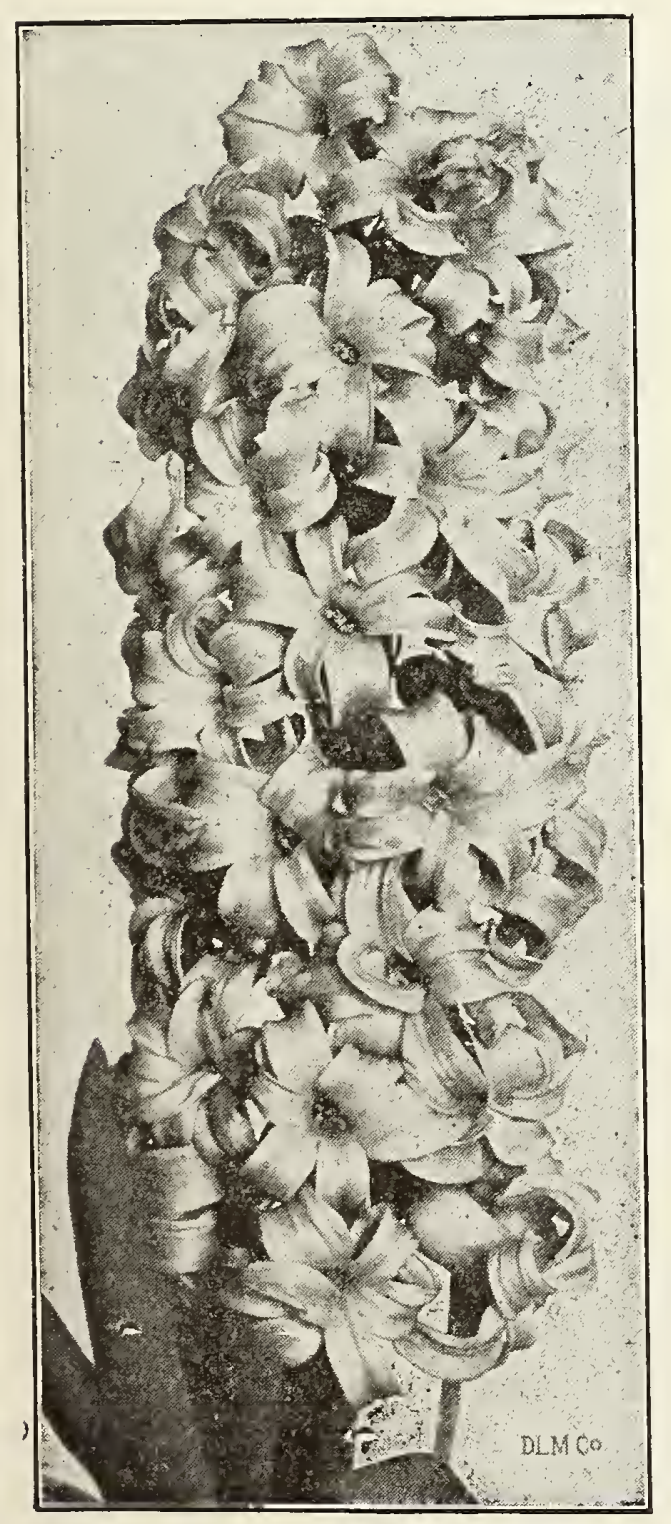

SPIKE OF SINGLE HYACINTH

\section{SINGLE RED AND ROSE.}

\begin{tabular}{|c|c|c|}
\hline BARON VON TH & $\begin{array}{c}\text { Each } \\
\$ 0.20\end{array}$ & $\begin{array}{l}\text { Doz. } \\
\$ 2.00\end{array}$ \\
\hline GARDINAL WISEMAN-Dark pink, full spike.. & 20 & 2.00 \\
\hline ETNA-Bright dark rose; large bells, splendid for pots or beds, late. & 20 & 2.00 \\
\hline GERTRUDE-Dark pink, fine spike, for pots or bedding. ....... & 20 & 2.00 \\
\hline GIGANTEA-Blush pink, small bells, compact spike....... & 20 & 2.00 \\
\hline LA VICTOIRE-Beautiful red, long well filled spike, & 20 & 2.00 \\
\hline MORENO & 20 & 2.00 \\
\hline ROI DES BELGES-Bright scarlet, fine for pots or beds.. & 20 & 2.00 \\
\hline
\end{tabular}

\section{SINGLE WHITE.}

ALBERTINE-Pure white, early ....................... 20

BARONESS VON THUYLL-Pure white, small bells, large fine com-

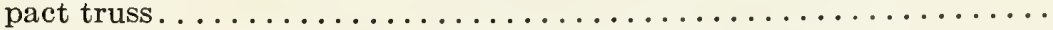

GRANDEUR A MERVEILLE-Blush white, large truss............. LA FRANCHISE-Creamy white, large bells and spike, good bedder
LA GRANDESSE-Snow white, immense bell, one of the best........ L'INNOCENCE-Pure white, fine for pots, early . . . . . . . . . . . . MADAM VAN DER HOOP-Almost pure white, fine.............

\section{SINGLE BLUE.}

ENCHANTRESS-Light blue, very long and full spike with large bells GRAND LILAS-Porcelain lilac, desirable for early forcing.......... GRANDIMAITRE-Deep lavander blue, shaded dark blue.......... JOHAN-Beautiful light blue, large, broad spike, splendid for bedding... KING OF THE BLUES-Rich dark blue, splendid............. LA PEYROUSE-Clear porcelain blue, large bells, fine for bedding. .... OUEEN OF THE BLUES-Clear light blue, large compact spike with

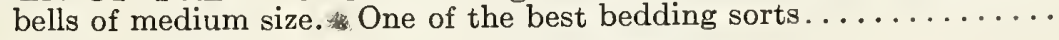
REGULUS-Light blue, fine for pots or bedding. . . . . . . . . . . 20

\section{SINGLE YELLOW.}

DUC DE MALAKOFF--Orange yellow. . . . . . . . . . . . . . . 20

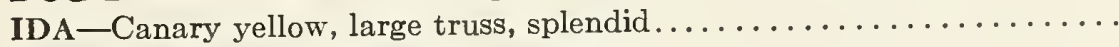

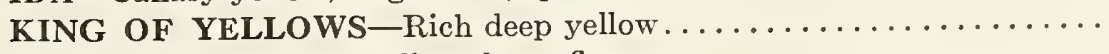

MAC MAHON-Pure yellow, large flowers................. 20

YELLOW HAMMER - Golden yellow, broad flower............ 20 


\section{Select Named Hyacinths}

\section{DOUBLE VARIETIES.}

The individual bells of the Doubles are large and beautiful, but there are usually fewer of them borne on the spike; for bedding and pot culture, however, Double Hyacinths are very satisfactory.

\section{Prices include postage at single and dozen rates.}

DOUBLE RED AND ROSE.

BOUQUET ROYAL, light rose, red center.

GROOTVORST, pink, large truss and bells . . .....

LORD WELLINGTON, pale blush, with delicate

rose stripe, large bells and massive spike..... did
NOBLE PAR MERITE, rose, large bells, splendid

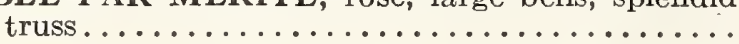

DOUBLE WHITE.

ISABELLA, pure white, fine spike.

LA TOUR D'AUVERGNE, pure white, large bells

LA VIRGINITE, blush white, dwarf, large bells...

PRINCE OF WATERLOO, pure white, large spike

$\begin{array}{cc}\text { Each } & \text { Doz } \\ 20 & \$ 2.00 \\ 20 & 2.00 \\ 20 & 2.00 \\ 20 & 2.00\end{array}$

DOUBLE BLUE.

Each Doz.

truss....... $20 \quad 2.00$

CHAS. DICKENS, dark lavender blue, large truss. $\quad 20 \quad 2.00$

GARRICK, lilac blue, with bright blue stripes.... $20 \quad 2.00$

REMBRANDT, dark porcelain, large bell....... $20 \quad 2.00$

\section{Second Size Named Hyacinths}

PRE-EMINENTLY SUITED FOR BEDDING_-The varieties being of one shade and size and blooming together will give more pleasing effects than Mixed varieties of Hyacinths, besides producing larger spikes. For description of varieties, see First Size Named.

\begin{tabular}{ll} 
Red and Rose & \multicolumn{1}{c}{ White } \\
Etna & Baron Von Thuyll \\
Moreno & Grandeur Marveille \\
Cardinal Wiseman & La Grandesse \\
Roi Des Belges & L'Innocence \\
La Victoire & Madam Vander Hoop \\
& Albertine \\
& La Franchise
\end{tabular}

Price including postage, $15 \mathrm{c}$ each; $\$ 1.50$ per doz.

\begin{tabular}{ll}
\multicolumn{1}{c}{ Blue } & \multicolumn{1}{c}{ Yellow } \\
Grand Lilas & Ida \\
Enchantress & McMahon \\
Grand Maitre & Herman \\
King of the Blues & \\
La Peyrouse & \\
Regulus & \\
Queen of the Blues & \\
Johan &
\end{tabular}

Yellow

Ida Mahon

Herman

BOUQUET D'ORANGE, reddish orange, fine spike $\begin{array}{lll}20 & 2.00\end{array}$ GOETHE, clear, pale yellow, large bells, fine truss $20 \quad 2.00$ $20 \quad 2.00$

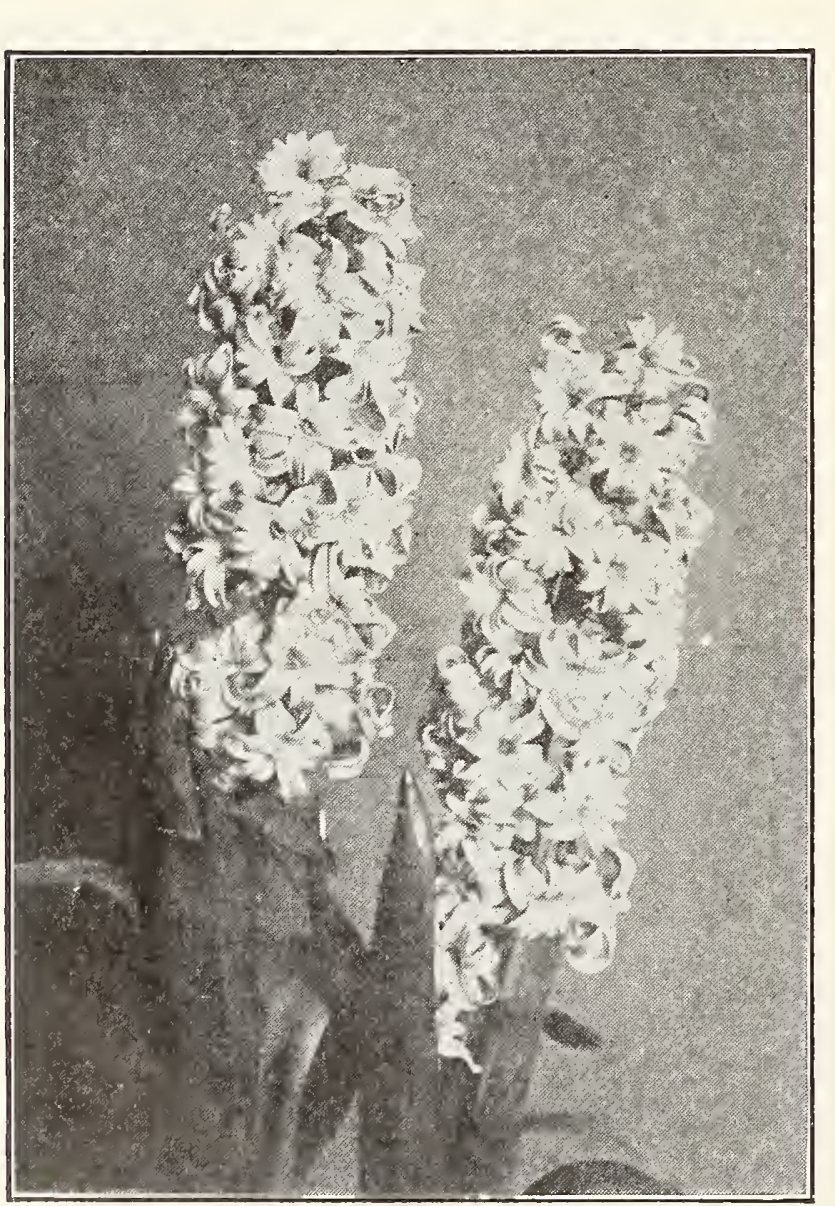

DUTGH ROMAN HYACINTHS.

Minature or Dutch Roman.

They may be planted close together in pots or boxes, also in beds in the open ground with charming effect. We can furnish them in the following colors: Dark Red, can furnish them in the following colors: $\begin{array}{lll}\text { Dark Red, } & \text { Rose and Pink, } & \text { Pure White, } \\ \text { Dark Blue, } & \text { Light Blue, } & \text { All colors mixed }\end{array}$ 6 cents each, 60 cents per dozen. $\$ 3.75$ per 100 .

\section{Choice Mixed or Un- Named Hyacinths}

\section{For Bedding and Forcing, in Separate Colors and Mixed Shades.}

These are made up of varieties selected for beds and borders, or for forcing for cut flowers.

SINGLE VARIETIES.

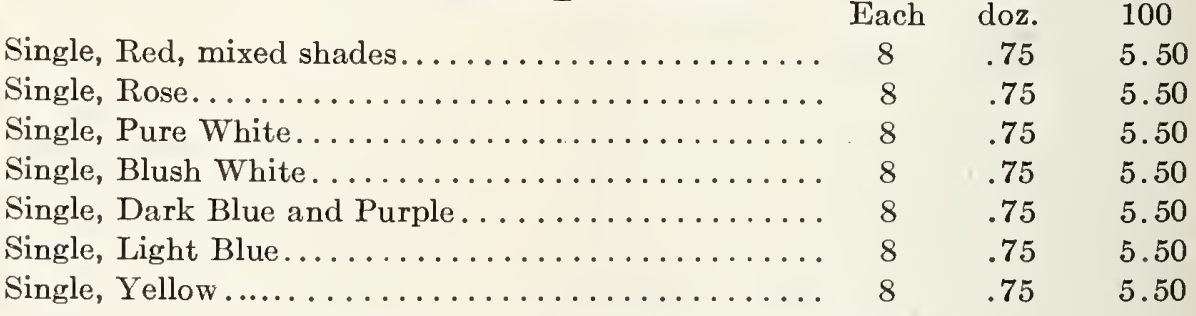

Single Mixed, All Colors, per 1000, $\$ 50.00$

DOUBLE VARIETIES.

Double, Red, mixed shades.................... $8 \quad 8 \quad .75 \quad 5.50$

Double, Rose.......................... $8 \quad 8 \quad .75 \quad 5.50$

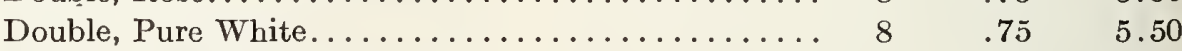

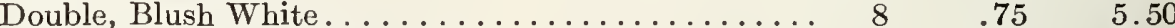

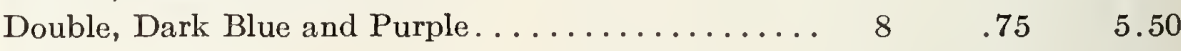

Double, Light Blue. . . . . . . . . . . . . . . . . . . $88 \quad .75 \quad 5.50$

Double Yellow........................ $8{ }^{2} \quad .75 \quad 5.50$

Double Mixed, all colors.................. $8 \quad .75 \quad 5.50$

\section{Per 1000, All Colors, $\$ 50.00$}

Early White French Roman Hyacinths.

We received word from our growers in France, just as this list was ready to go to press, that they could not ship us Roman Hyacinths as they were unable to secure a permit to export.

We would suggest the use of Dutch Minature Hyacinths and Freesias to take their place. 


\section{TULIPS}

For gorgeous and showy colors the Tulip is unsurpassed. Beds of Tulips in contrasting or blended shades bursting into a mass of gorgeous bloom after a dreary Winter, are of indescribable beauty and attractiveness. In pots they force easily, recuiring sarre treatment as for Hyacinths and produce best effects when 6 to 12 a re planted in a pan or box together. For beds treat as for Hyacinths, setting the bulbs four to five inches apart and three to four inches deep. If the soil is light plant deep, if stiff plant shallow.

The letters, a, b, c, following the varieties, indicate their earliness of bloom, the a's flower together, and are earliest, b next, etc. The figures indicate the height attained in inches, to aid in arranging flower beds.

\section{SINGLE EARLY TULIPS. NAMED SORTS.}

6 sold at dozen rates, 25 at 100 rates. Postage included at single and dozen rates. ARTUS, b7, scarlet, fine bold flowers, good for forcing and bedding

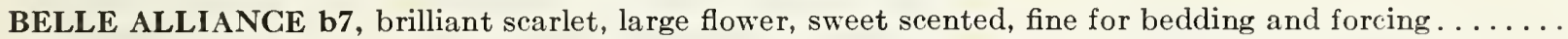
CHRYSOLORA b9, pure yellow, large and handsome flower; finest yellow bedder.

COTTAGE MAID b6, rosy pink, edged with white, a charming variety, for bedding and late forcing.....

CRIMSON BRILLIANT b9, brilliant scarlet. Splendid for forcing. Large flowers..

CRIMSON KING b9, scarlet, good bedder, medium size flower. .

DUCHESSE DE PARMA b9, brownish red with yellow border, large flower; good forcer and bedder

JOOST VAN VONDEL b9, red with white stripes. Large flower.

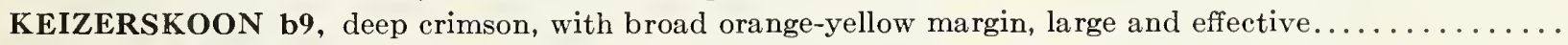

KING OF THE YELLOWS a9, deep golden yellow, splendid for cutting.

L'IMMACULEE a7, pure white, very early

LA REINE (Queen Victoria) b6, white slightly shaded rose; good variety for bedding or forcing. .

POTTEBAKER SCARLET a8, bright scarlet, very large and fine flower..

POTTEBAKER WHITE a8, pure white, fine large showy flower.

POTTEBAKER YELLOW a8, large, fine bright golden yellow, excellent forcer...

PINK BEAUTY b9, cherry rose, center of petals white, large flower, fine bedder

QUEEN OF THE NETHERLANDS b9, soft pink, very large globular fowers, excellent bedding variety

ROSE GRIS DE LIN b7, blush white shaded delicate pink.

ROSE LUISAN'TE $\mathbf{b 7}$, the best deep pink for forcing, large flower.

ROSE QUEEN b8, pink, pointed flowers. .

\section{SINGLE EARLY TULIPS.}

Superfine quality offered in separate colors and all colors mixed.

White.

Yellow.

Yellow

Red. . . . . . .
Pink and
Finest Mixed....

\section{DOUBLE EARLY TULIPS.}

Per Per

BOULE DE NEIGE b8, (White Paeony) pure white, large full flower resembling a white paeony.

COURONNE D'OR b8, golden yellow flushed orange-red, large flower..................

GLORIA SOLIS a7, deep crimson with broad golden margin, very large................

LA CANDEUR b8, pure white, extensively grown for bedding. ....................... IMPERATOR RUBRORUM b8, fine bright scarlet, large flower ......................
RILLO b8, blush white, shaded rose, large

URILLO b8, blush white, shaded rose, large
flowers, fine for forcing and bedding........

REX RUBRORUM b9, bright crimson scarlet, superb for bedding, large, showy............

RUBRA MAXIMA b7, deep red............
SALVATOR ROSA a8, deep rose, slightly flushed white, large flower, fine for beds

TEA ROSE a8, soft, pale yellow, flushed salmon, splendid for forcing. . . . . . . . . . . . . . . . . .
URNESOL RED AND YELLOW a

TOURNESOL RED AND YELLOW a7, rich scarlet, margined yellow, very early, one of the
best for forcing.........................

TOURNESOL YELLOW a7, bright yellow, shaded orange.....................

DOUBLE EARLY TULIPS.

IN SEPARATE AND MIXED GOLORS.

Per Per

Doz, $\quad 100 \quad 1000$

White.

Yellow.

Red..

Pink and Striped

$60 \$ 4.50 \$ 40.00$

$\begin{array}{rr}60 & 4.50 \quad 40.00\end{array}$

$\begin{array}{lll}60 & 4.50 & 40.00\end{array}$

$\begin{array}{lll}60 & 4.50 & 40.00\end{array}$

Finest Mixed.

$\begin{array}{lll}50 & 4.00 & 37.50\end{array}$

\section{EARLY TULIPS IN MIXTURES.}

\section{FOR BEDDING AND PO'TS.}

DUG VAN THOLL. The earliest of all; of dwarf habit. Fine for early forcing or bedding.

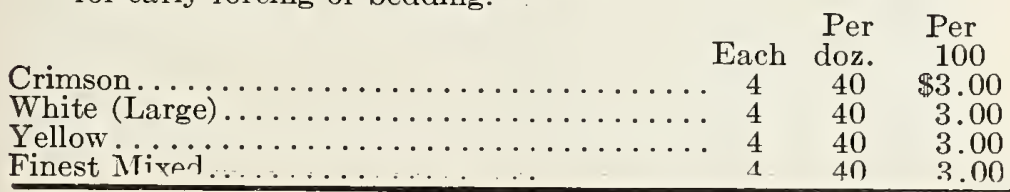

Each Per doz. Per 100

$\begin{array}{rrr}4 & 40 & \$ 2.75 \\ 6 & 55 & 3.75 \\ 6 & 55 & 3.75 \\ 5 & 50 & 3.60 \\ 6 & 60 & 4.00 \\ 5 & 50 & 3.60 \\ 6 & 55 & 3.75 \\ 5 & 45 & 3.00 \\ 5 & 50 & 3.50 \\ 6 & 55 & 3.75 \\ 5 & 50 & 3.75 \\ 6 & 60 & 4.00 \\ 5 & 50 & 3.25 \\ 6 & 60 & 4.00 \\ 5 & 50 & 3.50 \\ 9 & 1.00 & 8.00 \\ 5 & 50 & 3.50 \\ 5 & 50 & 3.50 \\ 6 & 60 & 4.00 \\ 6 & 60 & 4.05\end{array}$

$\begin{array}{lcr} & \text { Per } & \text { Per } \\ \text { Doz. } & 100 & 1000 \\ 60 & 4.50 & 40.00 \\ 60 & 4.50 & 40.00 \\ 60 & 4.50 & 40.00 \\ 60 & 4.50 & 40.00 \\ 50 & 4.00 & 37.50\end{array}$




\section{LATE OR MAY-FLOWERING TULIPS.}

Gorgeous flowers with long stems. Excellent for borders and with shrubbery.

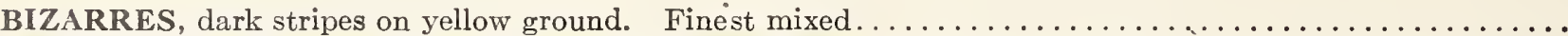

$\begin{array}{ccc}\text { Each } & \begin{array}{c}\text { Per } \\ \text { doz. }\end{array} & \begin{array}{c}\text { Per } \\ 100\end{array} \\ 4 & 40 & \$ 3.00 \\ 4 & 40 & 2.75 \\ 4 & 40 & 3.00 \\ 4 & 40 & 2.75 \\ 5 & 50 & 3.50 \\ 4 & 40 & 2.75 \\ 5 & 45 & 3.25 \\ 5 & 45 & 3.00 \\ 5 & 50 & 3.50 \\ 4 & 40 & 2.75 \\ 4 & 40 & 2.50\end{array}$

PARROT OR DRAGON TULIPS.

Fantastically shaped of gorgeous colors. Fine for forcing.

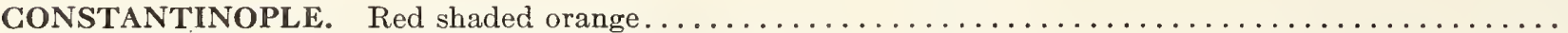

CRAMOISIE BRILLIANT. Brilliant crimson large flower. . . . . . . . . . . . . . . . . . .

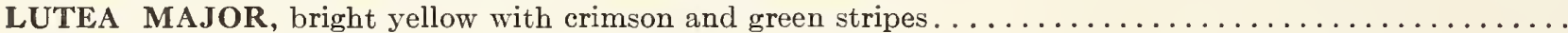

PERFECTA. Bright yellow, scarlet and green

ABOVE NAMED VARIETIES. Finest Mixed Parrot.

\section{DARWIN TULIPS.}

Large, robust flowers of remarkably brilliant colorings on long strong stems. They are truly the "Aristocrats" among garden tulips, and if forced slowly, succeed well in pots.

ASA GRAY, dark carmine.

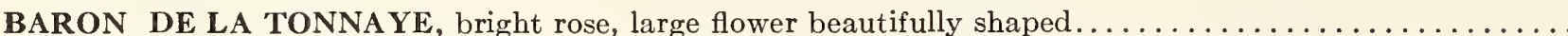

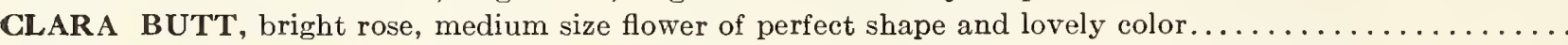

DREAM, soft lilac, very large.

GLOW, brilliant red...

GRETCHEN, light pink.

MADAM KRELAGE, soft lilac-rose, with

PRIDE OF HAARLEM, carmine rose. .

PAINTED LADY, milk white flushed with heliotrope, a beautiful flower resembling a water lily.........

THE SULTAN, maroon black with blue base, small flower of very fine form..................

Superfine Mixed..

$\begin{array}{crl}\text { Each } & \begin{array}{c}\text { Per } \\ \text { doz. }\end{array} & \begin{array}{l}\text { Per } \\ 100\end{array} \\ 5 & 50 & 3.00 \\ 5 & 50 & 3.50 \\ 4 & 40 & 2.75 \\ 4 & 40 & 2.75 \\ 4 & 40 & 2.50\end{array}$

$\begin{array}{ccc}\text { Each } & \begin{array}{c}\text { Per } \\ \text { doz. }\end{array} & \begin{array}{l}\text { Per } \\ 100\end{array} \\ 5 & 50 & 3.00 \\ 6 & 55 & 3.75 \\ 5 & 45 & 3.00 \\ 6 & 60 & 4.50 \\ 6 & 60 & 4.50 \\ 6 & 60 & 4.50 \\ 5 & 45 & 3.00 \\ 6 & 60 & 4.50 \\ 6 & 60 & 4.00 \\ 6 & 60 & 4.00 \\ 5 & 50 & 3.00 \\ 4 & 40 & 3.00\end{array}$

\section{GROGUS}

One of the earliest blooming bulbs, very pretty and effective when planted in the turf or in set beds.

Crocus should be planted in October or November. Set the bulbs two inches apart and cover with not more than two inches of earth. The named varieties make large blooms and are amirably suited for cultivation in pots, shallow bowls, window boxes, etc., and when so grown the roots should be planted closely together to produce a good effect.

\section{NAMED GROCUS.}

Price, all Varieties, doz. 30c; per 100, \$2.25.

Baron von Bruno-Dark Blue.

Cloth of Gold-Yellow and brown

Gloth of Silver-White and lilac.

Mont Blanc-Pure White.

Sir Walter Scott-White, blue striped.

Mammoth Yellow-Large bulbs.

\section{MIXED CROCUS}

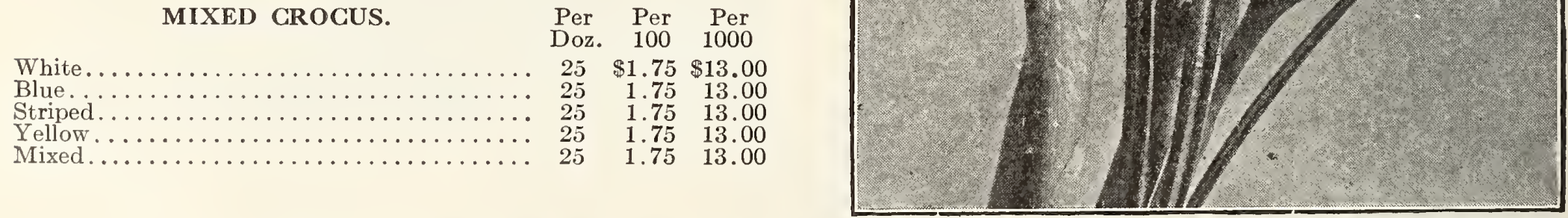

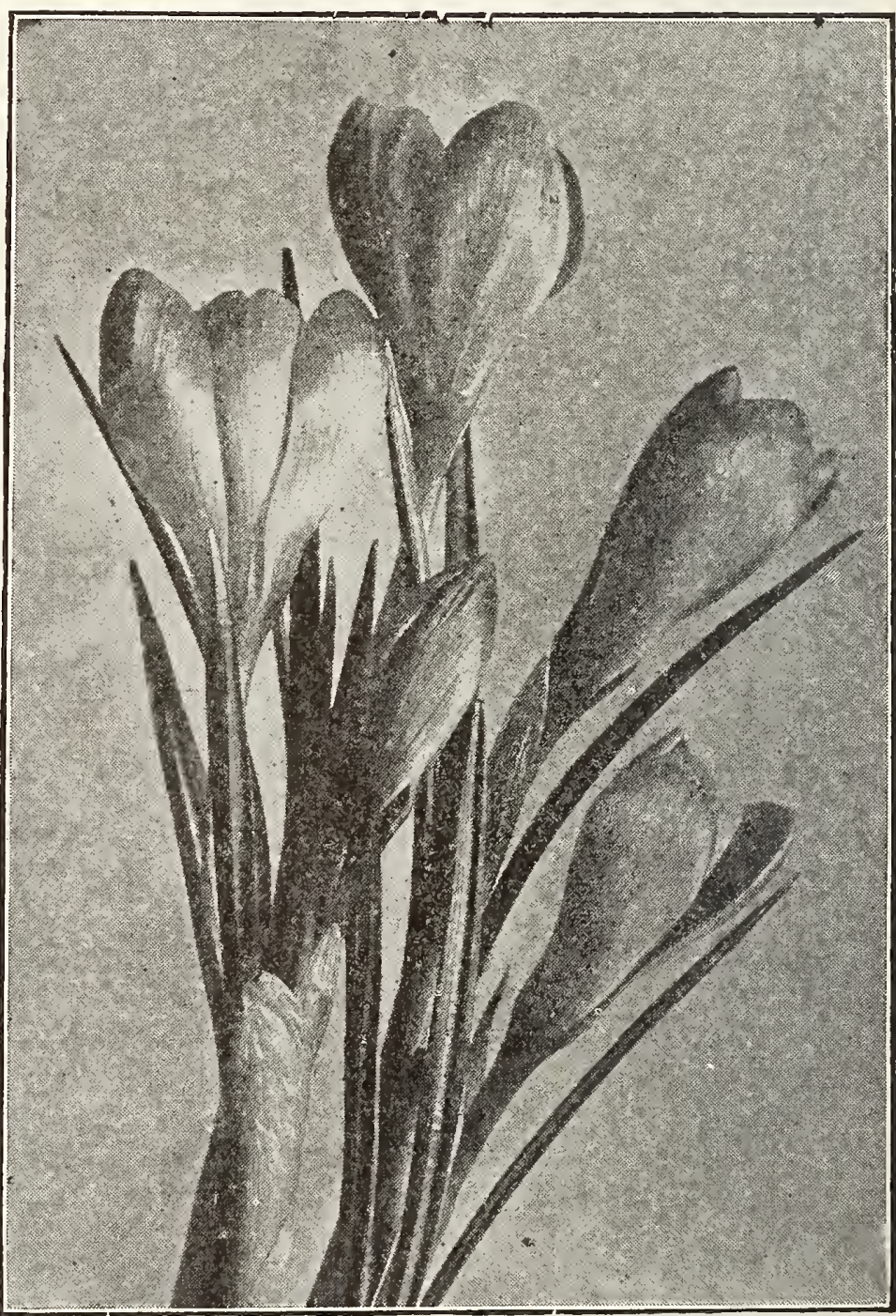




\section{Narcissus \\ COMMONLY CALLED JONQUILS, DAFFODILS, ETC.}

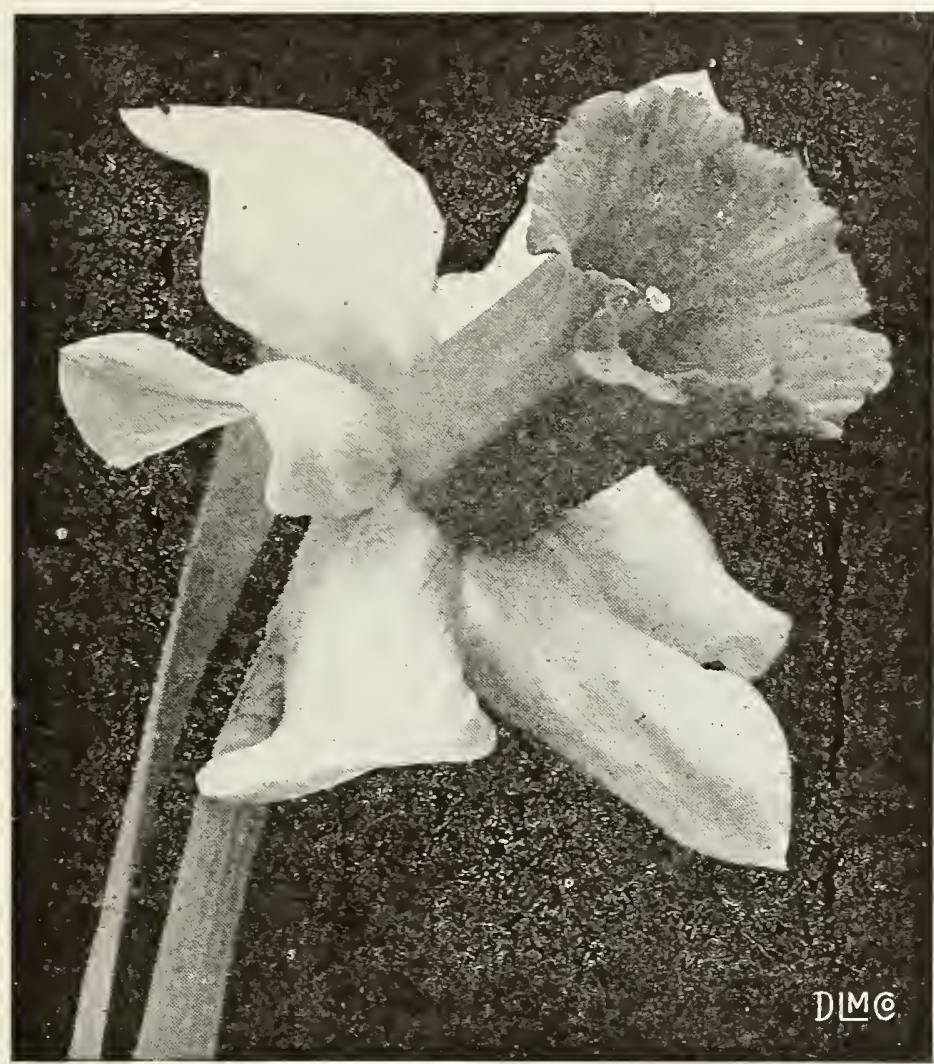

Among the most popular of all bulbs and wonderfully attractive in borders and among shrubbery as well as delightful for house decoration or wearing.

GULTURE-Among hardy varieties Emperor, Empress, Trumpet Major and Von Sion are excellent for growing in pots or trays, planting 12 or more together and treating like "Hyacinths in Pots." Out of doors they are planted about 3 inches deep in borders or clumps.

The double and single sorts are perfectly hardy and need not be disturbed oftener than once in three or four years, and not then unless they have become too much crowded by offsets. Plant in the Fall in good garden soil, about three or four inches deep and three to six inches apart.

\section{HARDY GARDEN NARCISSUS. Single Varieties}

BARRI CONSPICUUS. Yellow petals, cup edged with scarlet, extra for early EMPEROR. "One of the finest Daffodils in cultivation. Flower of the richest yellow; trumpet of immense size, the petals of the perianth measuring $31 / 2$ inches across

EMPRESS. A magnificent large variety. pure white, with yellow trumpet; bold and erect, and the best of the two-colored and erect, and the best of the two-colored

GOLDEN SPUR. True golden yellow, very early, excellent for forcing. One of the

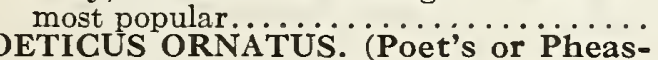
ant's eye.) Large pure white flowers, saffron cup, tinted with rosy scarlet; very

BICOLOR VICTORIA. White perianth SIR "With yellow trumpet. Very fine........ yellow, tinged bright orange. Extra for forcing. Long stems, extra large double nosed bulbs. fine forcer.

\section{Double Varieties}

$\begin{array}{ccc}\text { Each } & \begin{array}{c}\text { Per } \\ \text { doz. }\end{array} & \begin{array}{c}\text { Per } \\ 100\end{array} \\ 6 & 50 & \$ 3.50 \\ 6 & 60 & 4.00 \\ 6 & 50 & 3.50 \\ 5 & 50 & 3.50 \\ & & \\ 4 & 35 & 2.00 \\ 6 & 50 & 3.50 \\ & & \\ 6 & 50 & 3.50 \\ 5 & 40 & 2.50\end{array}$

ALBA PLENA ODORATA. The double Poeticus. Flowers pure white, large and very fragrant, one of the finest for all purposes. Each, 4c; per doz. 35̃c; per 100, $\$ 2.25$.

VON SION. The famous "Old Double Yellow Daffodil" rich golden yellow perianth and trumpet, one of the best forcing sorts. Each 5c; per doz. 40c; per 100, \$3.00.

\section{JONQUILS.}

Smaller flowers than Narcissus with shallow cups and of deep, golden yellow color.

SINGLE SWEET SCENTED, each 4c; per doz., 30c; per 100, \$2.00 DOUBLE SWEET SCENTED, each 4c; per doz., 35̌c; per 100,

CAMPERNELLE. The largest flowered Jonquil. Excellent for

forcing and cutting. Each 4; per doz., 30c; per $100 \$ 2.25$.

\section{POLYANTHUS NARGISSUS.}

For pot and greenhouse culture, blooming very early and producing their flowers in clusters.

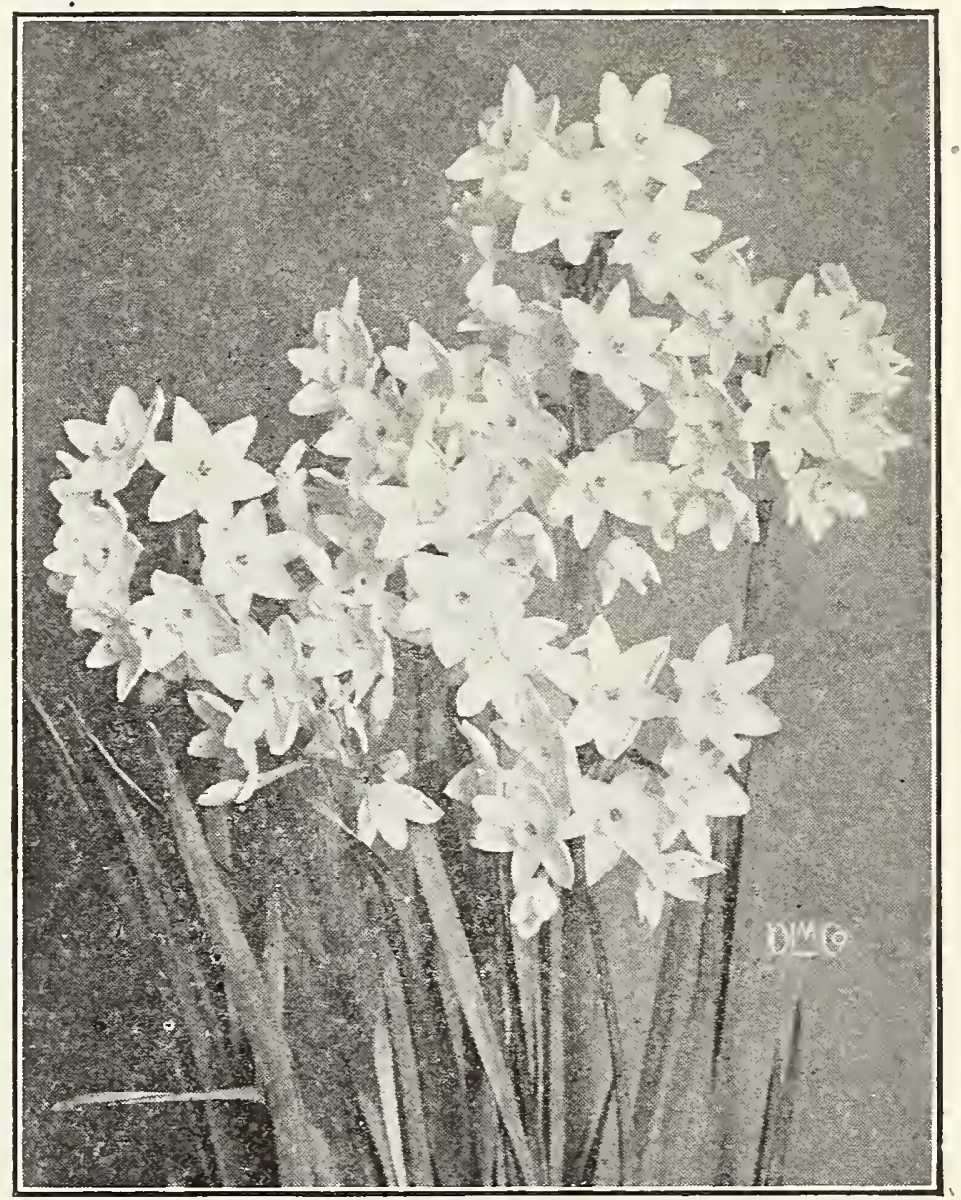

PAPER WHITE GRANDIFLORA NARCISSUS.

PAPER WHITE GRANDIFLORA. Large $\quad$ Per $\quad$ Per trusses of pure white flowers, splendid Each doz. 100 GRAND MONARQUE. Püe white flowers of largest size, with yellow cups; borne on large heads.................. $6 \quad 50 \quad 4.00$ GRAND SOLIEL D’OR. 'Rich yellow with $6{ }^{6} \quad 50 \quad 3.75$

\section{CHINESE SACRED NARCISSUS.} ORIENTAL NARCISSUS, SACRED LILY, JOSS FLOWER, ETC.

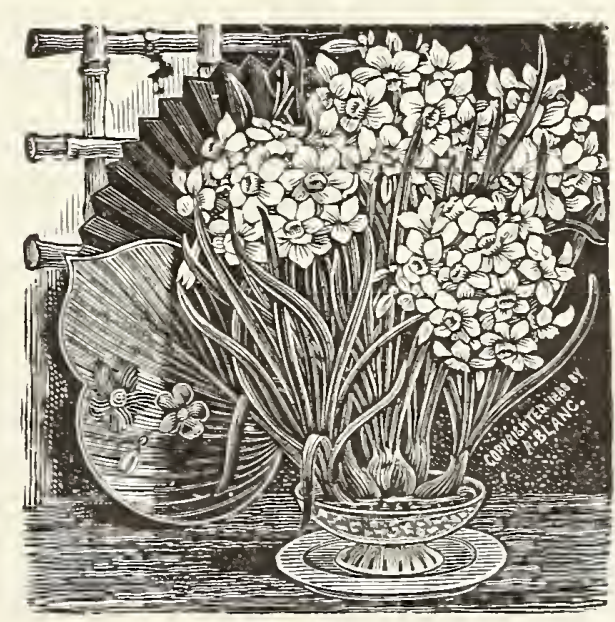

They grow well in pots of soil, but blost popular way of Chinese method as follows: of sand in a shallow bowl or some similar vessel, about four inches deep; place the bulb on this, and pack it firmly with small pebbles or pieces of rock; then fill it with water to the top of the pebbles and place in a warm sunny window. The bulb will at once commence a rapid growth and bloom in fresh water as often as

For a window ornament they are unexcelled and lend to an interior a cheerful aspect when all outside is frost-bound and dreary. The effect is heightened when several are put in a large dish. They can be planted at different times, and have a succession of flowers all Winter.

Flowers of ten double and single from the same bulb.

Extra Large Bulbs, each 15 cents.

Per dozen, $\$ 1.50$.

By Mail, Postage Extra, 15 cents per dozen. 


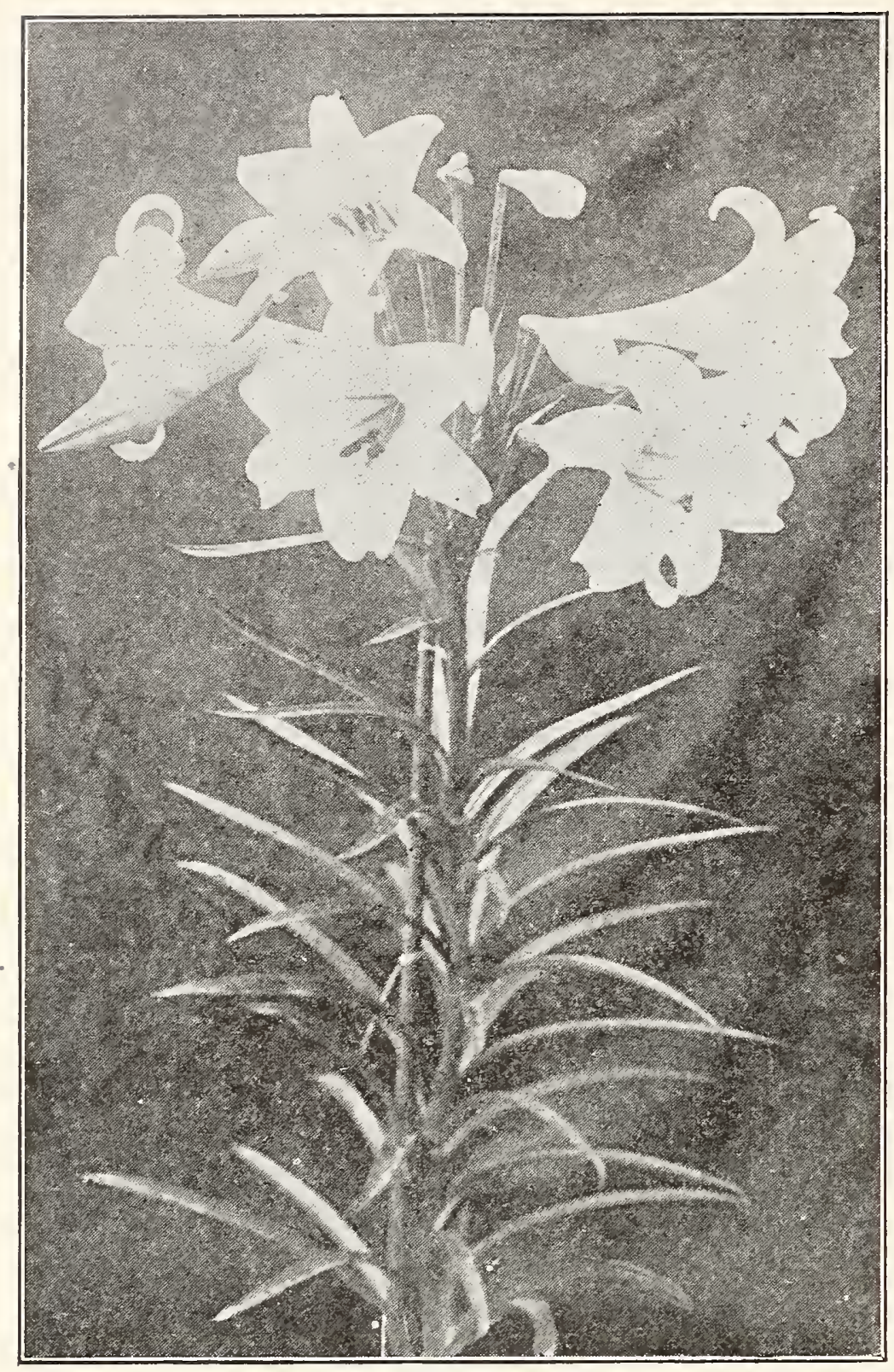

BERMUDA EASTER LILY

\section{FREESIA.}

One of the most popular and charming bulbs for pot culture, flowering in the Winter and Spring in the conservatory or window garden. Eight to twelve bulbs should be planted in a six-inch bulb-pan and covered one inch. They force readily, and can be had in bloom by Christmas if desired. The flowers are produced six to eight on stems about nine inches high and are particularly useful for cutting, remaining in good condition, kept in water, for two weeks.

PURITY - A new variety, magnificent, showy, glistening white

Very large on long stems. Large Bulbs, each $5 \mathrm{c}$; per doz., $50 \mathrm{c}$; per $100, \$ 2.50$.

REFRACTA ALBA.-Pure white with yellow blotched throat. Very fragrant.

Large Bulbs

Mammoth Buibs

Per doz. Per 100 $\begin{array}{rr}25 & \$ 2.50 \\ 30 & 3.00\end{array}$

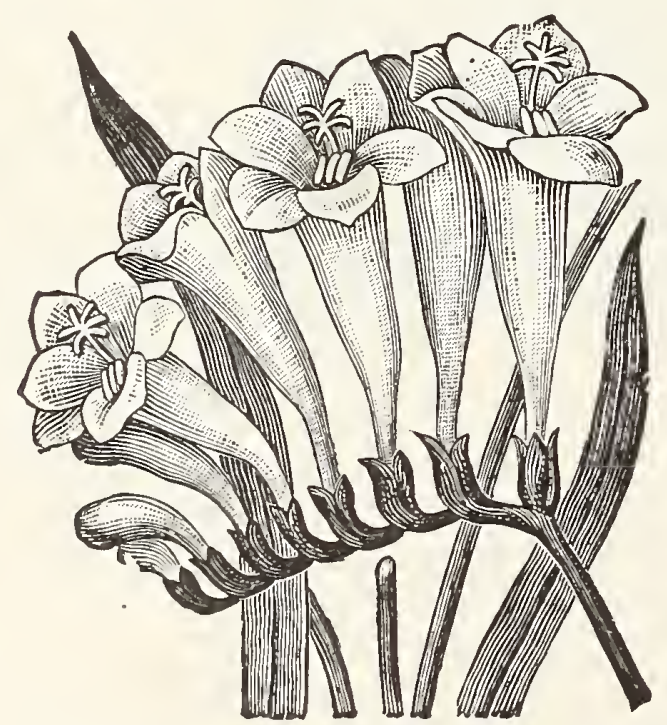

\section{LILIES}

\section{THE BERMUDA EASTER LILY.}

\section{(Lillium Harrisii.)}

The most popular and easiest of all Lilies for growing in pots GULTURE.- Plant in a 6 or 7 inch pot in good, loamy, rich soil setting the bulb 2 inches below the surface. Treat as for Hyacinths in pots.

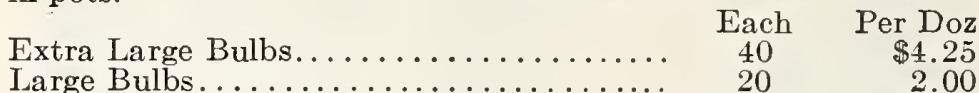

\section{LILIUM CANDIDUM.}

(Madonna Lily.)

A very early blooming variety of snowy whiteness, which is one of the most popular for garden and can be readily forced.

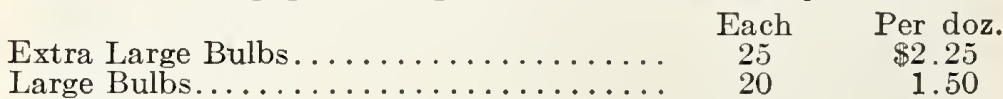

\section{Large Bulbs................}

Ready About November 1st.

"The golden Banded Lily of Japan." The flowers are pure white thickly studded with crimson spots while through the center of each pedal runs a clear golden band. May be grown in pots same as Lilium Harrisii.

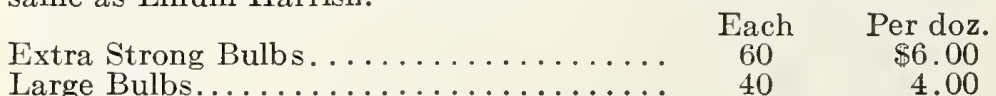

LILIUM SPECIOSUM.

Ready About November 1st.

"Japan Lily." The varieties of this class are magnificent border plants and excellent for pot culture. All are perfectly hardy and are among the most satisfactory. Lilies to grow.

ROSEUM, white, suffused and spotted with rose $\begin{array}{ccc}\text { Each } & \text { Per doz. } & \$ \$ \$ 400\end{array}$ RUBRUM, white, suffused and spotted crimson $40 \quad 4.00$

\section{GALLA LILIES.}

An old favorite, and of easy culture, the only requisite for successful culture is rich soil and plenty of water when growing. By allowing them to rest through the Summer an abundance of bloom may be had the next winter.

White Calla or Lily of the Nile. This old favorite is too well known to require any description.

Extra Large Bulbs.

Each Per doz

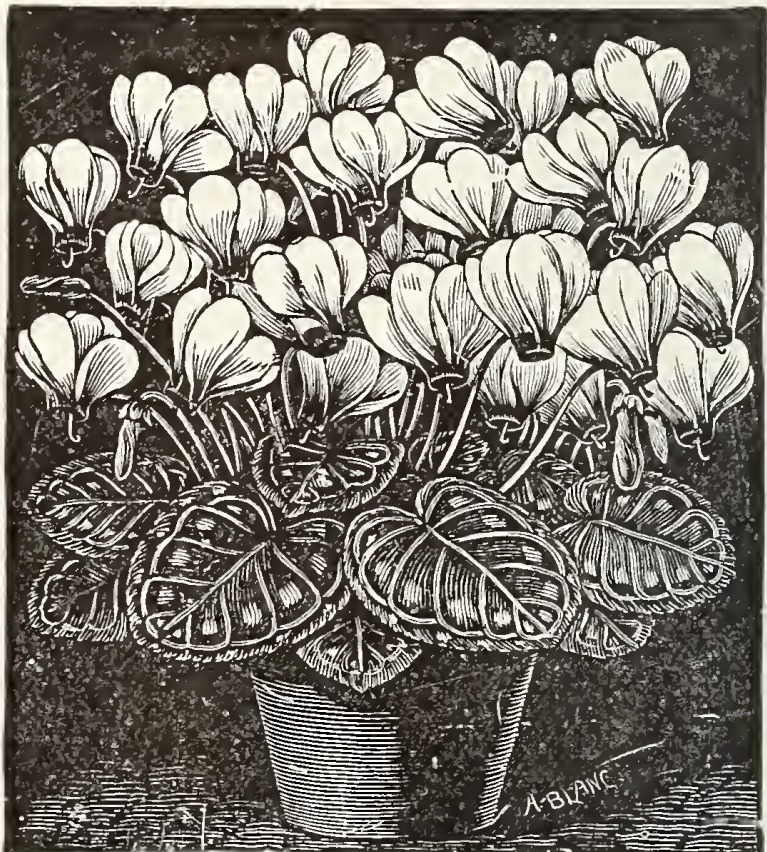

\section{GYCLAMEN PERSIGUM GIGANTEUM.}

One of the most beautiful and best adapted plants for Winter blooming in the house or greenhouse; grows readily and flowers freely for a long period; the foliage being handsomely mottled, is very ornamental. The bulbs should be planted in a compost of loam, leaf-mould and sand, ab out half covered, leaving the crown or top of the bulb clear; give a little water and keep in the shade until the leaves are well grown. Then, with plenty of light, air and temperature of about 60 degrees, they may be grown to perfection. pots should be plunged in a shady, sheltered place until October when they sould be repotted.

Finest Mixed Varities, price on request. 


\section{Fruit Trees}

Select thrifty young trees in preference to old or very large ones; the roots are more tender and fibrous and they bear transplanting better and are more apt to thrive; they can also be more easily trimmed and shaped to any desired form, and in the course of a few years will usually outstrip the older ones in growth. If not prepared to plant when your stock arrives, "heel in" by digging a trench deep enough to admit all the roots and setting the trees therein, carefully pack the earth about the roots, taking up when required. Never leave the roots exposed to the sun and air.

SENT BY EXPRESS OR FREIGHT AT EXPENSE OF PURCHASER.

\section{APPLES. \\ STANDARD.}

We can furnish all varieties usually catalogued, but the following list comprises the most desirable sorts:

4 to $5 \mathrm{ft}$., $70 \mathrm{c}$ each; $\$ 6.50$ per doz. 5 to $7 \mathrm{ft}$., $85 \mathrm{c}$ each; $\$ 8.25$ per doz.

\section{SUMMER VARIETIES.}

EARLY HARVEST-Pale yellow, fine flavor, August.

GOLDEN SWEET-Pale yellow, sweet and good; August.

OLDENBURG (DUCHESS OF OLDENBURG) - Large, striped over a greenish yellow ground.

RED ASTRACHAN-Large, crimson, juicy, with rich sub-acid flavor; hardy. July.

YELLOW TRANSPARENT-Pale yellow, good quality.

\section{AUTUMN VARIETIES.}

FALL PIPPIN-Very large, yellow, rich, aromatic. MAIDEN'S BLUSH-Large, beautiful, blush cheek. RAMBO-Yellow, streaked with red; October to December. RED BEITIGHEIMER-Pale cream, covered with crimson.

\section{WINTER VARIETIES.}

BALDWIN-Large, dark red, productive.

BEN DAVIS-Large, handsome, striped; good quality.

GANO-Deep red, fine quality; good shipper and keeper. GOLDEN RUSSET-Medium, dull russet, crisp, juicy.

GRIMES GOLDEN PIPPIN-Medium to large, skin golden yellow, flesh crisp, tender, juicy, long keeper. JONATHAN-Medium, red and yellow, flesh tender, juicy and
rich.

NORTHERN SPY - Large, striped red; good keeper.

RAWLE'S JANET-Medium, yellow striped with red, rich, crisp and juicy; a long keeper.

ROME BEAUTY - Large, yellow shaded red, tender.

SMITH'S CIDER-Medium, tender and juicy; sub-acid.

WHITE PIPPIN-Large, pale yellow, rich, sub-acid.

WINE SAP-Medium, deep red, rich, sub-acid.

\section{GRAB APPLES.}

5 to 7 feet.

Price, 85c each; $\$ 8.25$ per dozen.

HEWES CRAB FOR CIDER-Best cider crab grown.

YELLOW SIBERIAN-Golden amber, with red blush in sun.

HYSLOP-Deep crimson, very popular on account of its large size, beauty and hardiness.

TRANSCENDANT-Skin yellow, striped with red.

\section{PEARS.}

STANDARD AND DWARF.

4 to 6 feet, 75 cents each; $\$ 7.25$ per dozen.

BARTLETT-Large, clear, yellow, juicy. August. FLEMISH BEAUTY-Large, juicy, rich and fine; September to
October.

KIEFFER'S HYBIRD-Large, rich color and good quality.

LAWRENCE-Yellow, thickly dotted, fine flavor.

SECKEL-Small, yellowish brown, one of the best.

SHELDON-Large, round, russet-red. October.

TYSON-Large, yellow with brown cheek, sweet.

\section{QUINCES.}

4 to 5 feet; 85 cents each; $\$ 8.25$ per doz.

MEECH'S PROLIFIC-Fruit bright yellow; flesh very fragrant and tender; October.

ORANGE-Large bright golden yellow, fine quality; flesh firm, cooks tender. October.

\section{PEACHES.}

3 to 4 feet; 65 cents each; $\$ 6.00$ per doz.

4 to 6 feet; 75 cents each; $\$ 7.25$ per dozen.

CHAMPION-Creamy white with red cheeks, free-stone, excelient quality; early in August.

CRAWFORD'S EARLY-Large yellow, of good quality, freestone; early in September.

CRAWFORD'S LATE-Large, yellow with red cheek, freestone; last of September.

ELBERTA-Large, yellow with red chcek, flesh yellow; firm, juicy, of high quality, very prolific; September.

FITZGERALD-Large, yellow suffused with red, flesh deep yellow, best quality, hardy and productive; early September.

HEATH CLING - I arge, flesh white, juicy and melting; October. MOUNTAIN ROSE-Large, handsome red cheek, flesh white. juicy; one of the best; August.

OLD MIXON CLING-Large, yellow with red cheek; September. OLD MIXON FREE-Large, yellow with red cheek; September. SMOCK'S FREE-Large, yellow, very productive; late September.

\section{CHERRIES.}

HEART AND BIGARREAU (SWEET).

3 to 4 feet, 85 cents each; $\$ 8.25$ per dozen.

4 to 6 feet; $\$ 1.00$ each; $\$ 9.75$ per dozen.

BLACK TARTARIAN-Very large, purplish black, juicy, rich, excellent, productive; last of June.

GOVERNOR WOOD-Large, light red, juicy, rich, delicious. Tree healthy and productive; June.

NAPOLEON-Large, pale yellow, firm, juicy, productive.

ROCKPORT BIGARREAU-Large, yellow, juicy, and sweet.

YELLOW SPANISH-Large, pale yellow with light red cheek; late June.

DUKE AND MORELLO (SOUR).

$3 \frac{1}{2}$ to $4 \frac{1}{2}$ feet, 85 cents each; $\$ 8.25$ per dozen.

DYEHOUSE-A very early and sure bearer; ripens a week before Early Richmond; fine quality; June.

EARLY RICHMOND-Medium, dark red, fine quality.

ENGLISH MORELLO-Dark red, rich, acid, juicy, and good.

MAY DUKE-Large, red, and excellent variety.

MONTMORENCY-Large, red, fine flavor; finest acid cherry.

\section{PLUMS.}

STANDARD.

ON PLUM STOCKS, 4 to 5 feet; 85 cents each; $\$ 8.25$ per dozen.

ABUNDANCE-Large, yellow with heavy bloom, good quality, very prolific.

BEAUTY OF NAPLES-Medium size, green with purple cheek; abundant bearer.

BURBANK-The largest and best variety, color red, excellent quality, hardy and vigorous grower.

DAMSON-Small, oval fruit, purple, hardy, productive.

GERMAN PRUNE-Medium, oval fruit, purple, fine quality. GREEN SAGE-Small, delicious, very prolific, fine quality.

LOMBARD-Medium, red, juicy, hardy and productive.

PURPLE EGG-Rich purple, fine flavor, best market variety.

RED JUNE-Large, red, fine quality; strong, vigorous grower. Finest extra early plum.

\section{MULBERRIES.}

5 to 6 feet.

Price 1.00 each; $\$ 10.00$ per dozen.

DOWNING'S EVERBEARING-One of the most prolific varieties, bearing an abundance of large, black, sub-acid fruits, hardy; fruits about three months.

NEW AMERICAN-An everbearing variety; large fruit of the finest flavor; hardy; fruits about three months. 


\section{Grape Vines, Small Fruits, Asparagus, Etc.}

\section{GRAPE VINES.}

\section{All Two-Year-Old Selected Stock. Black or Purple Grapes.}

CAMPBELL'S EARLY-Bunch and berry large, glossy, black, sweet and juicy; fine quality.........30 each; $\$ 3.25 \mathrm{doz}$. CONCORD-Large, black grape, hardy and productive; juicy and sweet..................... each; $\$ 3.25$ doz.

EARLY OHIO-Earliest black grape known; healthy and vigorous grower..................40 each; $\$ 4.00$ doz.

EATON-Bunch and berries very large, skin black and finest quality.....................50 each; $\$ 5.50 \mathrm{doz}$. *IVES' SEEDLING-Dark purple, sweet. . . .30c each; $\$ 3.25$ doz.

\section{Red Grapes.}

BRIGHTON-Bunch large, berries large, red, round, excellent flavor; one of the earliest..........40 each; $\$ 4.00 \mathrm{doz}$.

*CATA WBA-Berries large, round; when ripe a dark copper color; sweet, rich, musky flavor............ 35 cach; $\$ 3.75$ doz.

DELAWARE-Small, light red, thin skin, very juicy, sweet, fine flavor. ...............40 each; $\$ 4.00 \mathrm{doz}$.

\section{White or Yellow Grapes.}

NIAGARA-Vine remarkably hardy and strong grower; bunches very large and compact; berries large, greenish white, slightly ambered in the sun; skin thin but tough, and does not crack. .30c each; $\$ 3.25$ doz.

POCKLINGTON-A seedling of the Concord, resembling that variety in leaf, vine, habit of growth, hardiness and producvariety in leaf, vine, habit of growth, hardiness and productiveness. Bunch and berry very large; attractive golden Varities marked with a ${ }^{*}$ are best for arbors.

\section{BLACKBERRIES.}

60 cents per Dozen. $\$ 4.50$ per 100 .

ANGIENT BRITON-Large fruit, stems loaded with good sized berries of fine quality; vigorous grower, hardy.

EARLY HARVEST - Very prolific, choice variety.

BLOWER'S (new). Large, lucious berries, rich in quality and quantity

ELDORADO-Large fruit, borne in clusters and ripen well together, fine quality, good keeper.

MERSEREAU (new)-Extremely hardy, berries sweet, rich, melting and luscious without core. Good keeper and shipper.

SNYDER-Medium size, sweet and juicy; extremely hardy and very productive.

\section{DEWBERRY}

LUCRETIA-One of the low-growing, trailing blackberries. In earliness, size and quality it equals any of the tall-growing sorts. It has proved highly satisfactory wherever tried, and many say it is the best of all the blackberry family. $60 \mathrm{c}$ per doz.; $\$ 4.50$ per 100 .

\section{CURRANTS.}

30 cents Each; $\$ 3.25$ per Dozen.

BLACK GHAMPION-Large bunch and berry, excellent quality, strong grower, very productive.

CHERRY - Fruit large, bunch small, deep red, acid.

FAY'S PROLIFIC-Extra large stems and berries, color rich red, fine quality, very productive.

POMONA-Bright red, extra fine quality and enormously productive; strong, vigorous grower.

RED DUTCH-An old favorite variety with large red berries.

WHITE GRAPE-Large, yellowish white, sweet, excellent quality and valuable for the table.

\section{GOOSEBERRIES.}

DOWNINGS-Very large and fine quality.......\$3.25 doz HOUGHTON-Medium size, very productive....... $3.25 \mathrm{doz}$. SMITH'S IMPROVED-Large, thin skin, best for

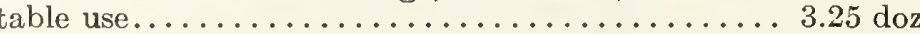

\section{RASPBERRIES.}

50 cents per Dozen; $\$ 4.50$ per 100.

RED JACKET-Large size, light crimson color, good quality and firm, vigorous and productive. One of the best, welltested, large early berries for the North.

GUMBERLAND-The largest black cap; a healthy, vigorous grower; very productive and of finest quality.

GUTHBERT - Large, firm, deep rich crimson, of excellent quality, tall, strong, vigorous, perfectly hardy and very productive. Ripens medium to late.

GREGG-A large black variety, fruit firm, of excellent quality and a good shipper.

\section{SPRING STRAWBERRIES.}

25 plants 50 cents; 100 plants $\$ 1.50 ; 1,000$ plants $\$ 12.00$.

AROMA (Per.)-One of the finest for long distance shipping. The large berries are bright red to the center. Of conical shape, with prominent yellow seeds that help to make them very attractive on market. The quality is such that it is a leader with many growers.

BURBACH (P) (Imp.)-This variety is famous for its beautifully colored, large berries and mammoth crops.

GANDY (Per.) - Another old favorite. Its popularity, instead of decreasing, is steadily increasing. The fruit is a dark red with dark red seeds. A very late berry that does best on a heavy clay soil. Should be planted with the Senator Dunlap as fertilizer.

HAVERLAND (Imp.)-It has always proven to be one of the best varieties wherever planted, and thrives best with the Senator Dunlap as fertilizer.

HERITAGE (Per.)-The plants of this variety are good growers. The fruit is unusually large for one that continues to bear throughout the berry season.

SENATOR DUNLAP (Per.)-The demand for this variety has been increasing steadily, as it has an unusually long fruiting season. It bears immense quantities of large, handsome, rich fine-flavored, dark red berries.

\section{FALL BEARING STRAWBERRIES.}

Superb and Progressive. $\$ 3.50$ per 100 .

\section{ASPARAGUS ROOTS.}

May be either planted in fall or spring. Dig up your ground deep, put plenty of well-rotted manure thoroughly mixed in the soil, throw out a bed about four to five inches deep, lay the plants in by spreading the roots out well and scatter the dirt over the plants about four inches, or the depth of the ground thrown out, firm the fidirt well around the plants by patting it down with spade or shovel, then top dress the ground with about three inches of well-rotted manure, and scatter salt enough over the top of this to make the ground white enough to track a rabbit. The second year after planting you will be able to harvest enough asparagus for a good-sized family from a bed of about 200 plants. You can plant about 200 plants in a bed three feet wide and fifteen feet long. You should keep the crown of the asparagus cut regularly so it will produce from three and one-half to seven pounds of asparagus, and when planted in small beds, where it can be well mulched and cared for, will even do much better than this. It is necessary to start with good roots. It depends much more on the care taken of the plants and the plant food given them than it does the variety planted. Salt should be put on at the end of every season, in the spring of the year.

\section{ASPARAGUS ROOTS-Two-year-old roots.}

Per Per Per

$100 \quad 500 \quad 1,000$

Barr's Mammoth.............. \$1.20 \$5.00 \$8.00 Columbia Mammoth White......... $1.20 \quad 5.00 \quad 8.00$

Conover's Colossal.............. $1.00 \quad 4.00 \quad 7.00$

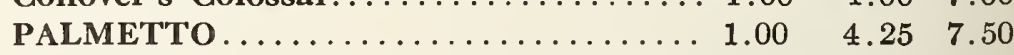

DISTANGES FOR PLANTING. Grapes, rows 10 to 16 feet apart, 7 to 10 feet in rows. Blackberries, 6 to 7 feet apart, 3 to 5 feet in rows. Currants, 4 feet apart each way. Gooseberries, 4 feet apart each way. Raspberries, rows 5 feet apart, 3 feet in rows. Strawberries, for field culture, rows 3 to $31 / 2$ feet apart, 1 to $1 \frac{1}{2}$ feet in rows; for Garden Culture, plant in beds 4 feet wide, 3 rows in each bed, plants 1 foot apart in rows. 


\section{EVERGREENS}

\section{JUNIPER. Juniperus.}

Irish-A distinct and beautiful variety, of erect dense, conical outline, resembling a pillar of green; very desirable singly, as a hedge, or for massing. 2 to $3 \mathrm{ft}$., each $\$ 1.50$.

Virginiana (Red Cedar)-A well known American tree, varies much in habit and color of foliage, some being quite stiff, regular and conical; others loose and irregular. It makes a fine ornamental hedge Plant. 2 to $3 \mathrm{ft}$., each $\$ \mathbf{1 . 7 5}$.

Savin (Sabina)-A dwarf spreading shrub with trailing branches, thrives in the poorest soils. Very suitable for rockwork. 15 to 18 inches, each $\$ 1.50$.

\section{PINE. Pinus.}

Austrian-A remarkably robust, hardy variety with long leaves, stiff and dark green. It is one of the most valuable sorts, growing rapidly, and of spreading habit. 2 to $3 \mathrm{ft}$., each \$1.25.

Strobus (White Pine)-A very beautiful and graceful pine, regular in form with horizontal boughs and dark green foliage, growing quite tail, surmounted by a symmetrically formed crown. 2 to $3 \mathrm{ft}$., each $\$ 1.25$.

\section{SPRUCE. Picea.}

Erect growing trees, leaves needle shaped, scattered around the shoots.

Colorado Blue (Pungens Glauca)-One of the hardiest and most beautiful of all Spruces; similar in form and habit to the white Spruce, but the foliage is of rich blue or sage color. 2 to $3 \mathrm{ft}$., each $\$ 4.00$.

Koster's Blue-Similar to the preceding, except the foliage is much brighter blue; very rare. 2 to $3 \mathrm{ft}$., each $\$ 5.50$.

Douglas'-Large, conical form; with spreading branches, horizontal; leaves light green above, glaucous below. A valuable evergreen tree. 2 to $3 \mathrm{ft}$., each $\$ 4.50$.

\section{Hedge Plants}

Althea-See page 11 .

Barberry Thunbergii-For description see page 11. $11 / 2$ to $2 \mathrm{ft}$., per $100, \$ 20.00$.

\section{SPRUGE.}

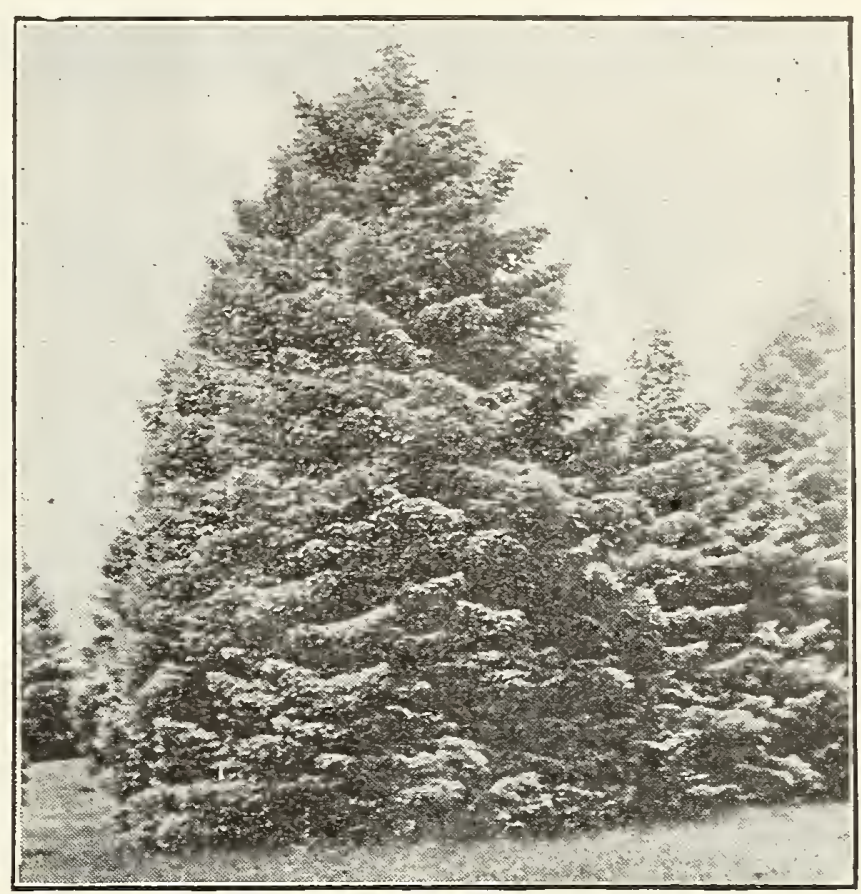

\section{NORWAY SPRUCE.}

Norway (Excelsa)-An elegant tree which is extremely hardy, of rapid growth, lofty, pyramidal form. Branches assume a graceful, drooping habit when the tree attains 15 to 20 feet in height. One of the most popular evergreens for planting, either as single specimen trees, or in masses, for effect or shelter. A splendid evergreen hedge plant. 2 to $3 \mathrm{ft}$., each, $\$ 1.25$.

Norway Weeping-A pendulous variety, the lateral branches drooping gracefully. 2 to $3 \mathrm{ft}$., $\$ 1.75$.

Norway Golden-One of the most beautiful and effective of evergreens, its young shoots contrasting brilliantly with the old undropped foliage. Similar in growth and characteristics to the Norway. 2 to $3 \mathrm{ft}$., each, $\$ \mathbf{1 . 7 5}$.

Locust, Honey-Well known shrubs and trees with long, sharp thorns. 12 to 15 inches, per 100, $\$ 5.00$.

Osage Orange -12 to 15 inches, per $100, \$ 5.00$.

\section{Privet}

All varieties of Privet are almost evergreen; grow freely in all soils; are compact and regular in form and bear shearing to almost any extent. They are valuable for groups in lawns. Bloom freely in June and July.

Planting-Can be set either in single rows about 12 inches apart, or in double 8 inch rows, setting the plant's alternately 12 inches apart. Double rows make thicker more compact hedges.

California-A vigorous hardy variety of fine habit and foliage. It is free growth, succeeds under adverse conditions and does faily well under trees. The most commonly planted of all Privets. $11 / 2$ to $2 \mathrm{ft}$., per doz. \$1.00; per 100 $\$ 4.00$. 2 to $3 \mathrm{ft}$., per doz. $\$ 1.00$; per $100 \$ 6.00$.

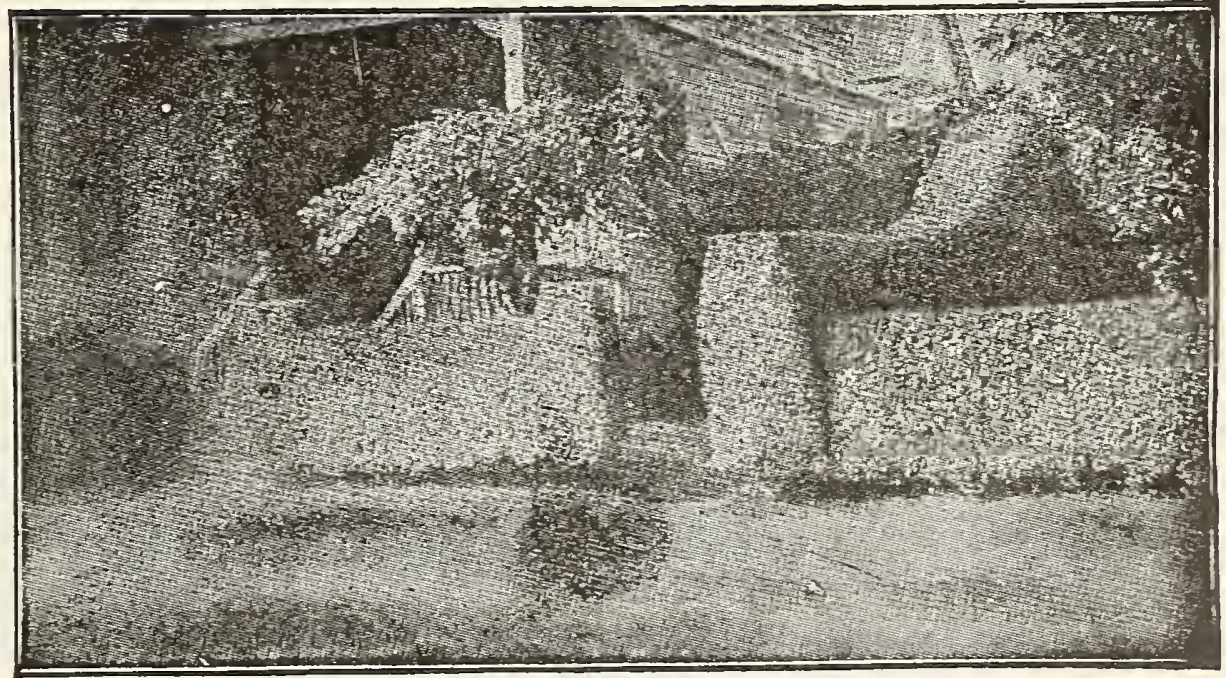

California Privet Hedge.

EVERGREEN HEDGE PLANTS.

ARBOR VITAE.

American -15 to 20 inches. $\$ 40.00$ per 10 ?

NORWAY SPRUCE-15 to 20 inches. $\$ 40.00$ per 100. 


\title{
Deciduous Shade and Ornamental Trees.
}

\author{
FOR LAWN, STREET AND FOREST PLANTING.
}

Strictly selected, all first quality. Ask for special prices in large quantities. When Caliper is stated (in inches) it is taken 1 foot from the ground line.

\begin{tabular}{|c|c|c|c|c|c|}
\hline AILANTHUS, (Tree of Heaven)......8 to $10 \mathrm{ft}$. & $\begin{array}{l}\text { Each } \\
\$ 1.25\end{array}$ & $\begin{array}{l}\text { Per } 10 \\
\$ 10.00\end{array}$ & LARCH. & $\begin{array}{l}\text { Each } \\
\$ 1.25\end{array}$ & $\begin{array}{l}\text { Per } 10 \\
\$ 11.00\end{array}$ \\
\hline $\begin{array}{l}\text { LDER, (Alnus) European.......... } 8 \text { to } 10 \mathrm{ft} \text {. } \\
\text { LDER, Imperial Cut Leaved....... } 8 \text { to } 10 \mathrm{ft} \text {. }\end{array}$ & $\begin{array}{l}1.00 \\
1.25\end{array}$ & & $\begin{array}{l}\text { INDEN, American.. } \\
\text { INDEN, American. }\end{array}$ & & $\begin{array}{l}11.00 \\
14.00\end{array}$ \\
\hline 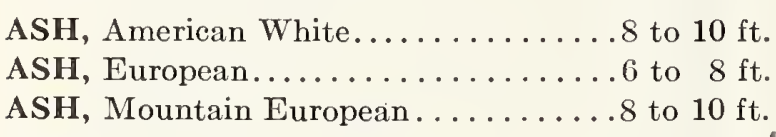 & $\begin{array}{l}1.00 \\
1.25 \\
1.25\end{array}$ & $\begin{array}{l}10 . \\
10 .\end{array}$ & $\begin{array}{l}\text { LINDEN, European Broadleaf. . } \\
\text { LINDEN, European Broadleaf. . }\end{array}$ & $\begin{array}{l}1.50 \\
2.25\end{array}$ & \\
\hline 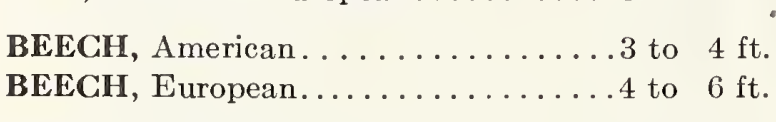 & $\begin{array}{l}1.50 \\
1.50\end{array}$ & 14.00 & LIQUIDAMBER-Sweet Gum & 1.50 & 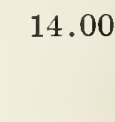 \\
\hline 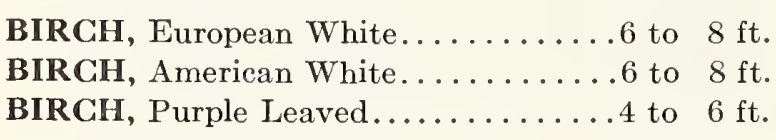 & $\begin{array}{l}1.50 \\
1.25\end{array}$ & & $\begin{array}{l}\text { esembling maiden hair fern. } \\
\text { d elegant............... } 6 \text { to } 8 \mathrm{ft} \text {. }\end{array}$ & 1.50 & 14.0 \\
\hline $\begin{array}{l}\text { BIRD CHERRY, (Prunus Padus).....6 to } 8 \mathrm{ft} \text {. } \\
\text { BOX ELDER, (See Maple Ash-Leaved). }\end{array}$ & 1.25 & & 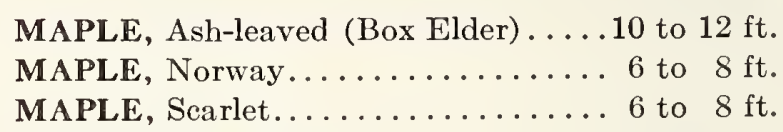 & $\begin{array}{l}1.00 \\
1.70 \\
2.50\end{array}$ & $\begin{array}{r}9.00 \\
16.00 \\
24.00\end{array}$ \\
\hline BUGKEYE, Ohio & 1.50 & 14.00 & $\begin{array}{l}\text { MAPLE, Schwedlerii............ } \\
\text { MAPLE, Silver......... } 6 \text { to } 8 \mathrm{ft} \text {. }\end{array}$ & $\begin{array}{l}2.50 \\
1.25\end{array}$ & $\begin{array}{l}24.00 \\
11.00\end{array}$ \\
\hline 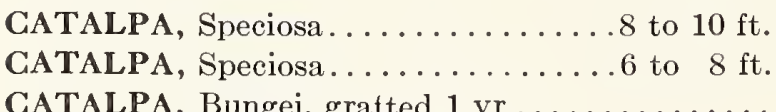 & $\begin{array}{l}1.50 \\
1.25 \\
1.75\end{array}$ & & $\begin{array}{l}\text { MAPLE, Sugar or Rock.......... } 6 \text { to } 8 \mathrm{ft} \text {. } \\
\text { MAPLE, Weir's Cut-leaved........ } 8 \text { to } 10 \mathrm{ft} \text {. }\end{array}$ & $\begin{array}{l}1.25 \\
1.25\end{array}$ & 11.0 \\
\hline $\begin{array}{l}\text { CATALPA, Bungei, grafted } 1 \mathrm{yr} \\
\text { CATALPA, Bungei, grafted } 2 \mathrm{yr} \text {. }\end{array}$ & $\begin{array}{l}1.75 \\
2.00\end{array}$ & & 8 to $10 \mathrm{ft}$. & 2.00 & 20.0 \\
\hline GHERRY, Japan Flowering......... to $6 \mathrm{ft}$. & ( & & $\begin{array}{l}\text { ish } \ldots \ldots \ldots \ldots \ldots \ldots \ldots \\
\ldots \ldots \ldots \ldots \ldots \ldots \ldots\end{array}$ & $\begin{array}{l}2.75 \\
2.25\end{array}$ & $\begin{array}{l}25.0 \\
21.0\end{array}$ \\
\hline RAB APPLE, Bechtel's double Fl'g. . 2 to $3 \mathrm{ft}$. & 1.00 & & 6 to $8 \mathrm{ft}$. & 2.00 & 19.0 \\
\hline GRAB APPLE, Bechtel's double Fl'g. . 3 to & 1.50 & 14.00 & t.............. & 2.00 & 0 \\
\hline GYPRESS, Deciduous..............6 to $8 \mathrm{ft}$. & 2.00 & & OAK, White................... 4 to $6 \mathrm{ft}$. & 1.50 & 14. \\
\hline $\begin{array}{l}\text { E, (Paulownia Im- } \\
\ldots \ldots \ldots \ldots \ldots \ldots \ldots+4 \text { to } 6 \mathrm{ft} \text {. }\end{array}$ & 5 & 10.00 & -See Empress Tree. & & \\
\hline 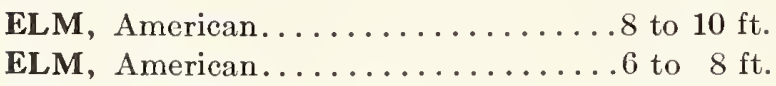 & $\begin{array}{r}1.00 \\
85\end{array}$ & & PEACH, Flowering Red and & 1.00 & 9. \\
\hline 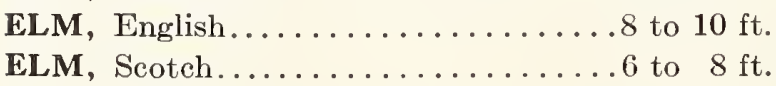 & $\begin{array}{l}1.50 \\
1.50\end{array}$ & & PERSIMMON, American... & 75 & 7. \\
\hline. .8 to $10 \mathrm{ft}$. & 2.00 & & ... o to o rt. & 50 & \\
\hline $\begin{array}{l}\text { ORSE GHESTNUT, White Fl'g....6 to } 8 \mathrm{ft} \text {. } \\
\text { ORSE CHESTNUT, Red Fl'g.....4 to } 5 \mathrm{ft} \text {. }\end{array}$ & $\frac{1}{2}$. & 20.00 & $\begin{array}{l}\text { POPLAR, Lombardy ............8 to } 10 \mathrm{ft} \text {. } \\
\text { POPLAR, Balsam (Balm of Gilead)...10 to } 12 \mathrm{ft} \text {. }\end{array}$ & $\begin{array}{r}75 \\
1.25\end{array}$ & \\
\hline
\end{tabular}

\section{WEEPING AND DECIDUOUS TREES.}

\begin{tabular}{|c|c|c|c|c|}
\hline & & & Each & $\begin{array}{l}\text { Per } 10 \\
\$ 8.00\end{array}$ \\
\hline SH, WEEPING (Fraxinus Pendula) 1 yr.. & $\$ 2.00$ & SYGAMORE, American.. & & $\$ 8.00$ \\
\hline IRCH, Cut-leaved.. & 2.50 & SYGAMORE, European.. & 1.25 & 11. \\
\hline HERRY, Japan, 2 yr, head. & 2.50 & THORN, (Crataegus) Pa & & \\
\hline amperdown & 2.50 & THORN, Double & & \\
\hline IULBERRY, Weeping, 2 y] & 3.75 & TULIP TREE. & 1.20 & \\
\hline VILLOW, Babylonica... & 1.50 & TULIP TREE..... & 2.75 & \\
\hline NILLOW, Thurlo & 1.75 & WILLOW, Royal. . & 1.50 & \\
\hline $\begin{array}{l}\text { TRAWBERRY TREE, } \\
\text { European) } . . \ldots \ldots \ldots\end{array}$ & 1.25 & $\begin{array}{l}\text { WILLOW, Golden Bark.......... } 8 \text { to } 10 \mathrm{ft} \\
\text { WILLOW, Laurel-Leaved......... } 8 \text { to } 10 \mathrm{ft}\end{array}$ & $\begin{array}{l}1.75 \\
1.75\end{array}$ & \\
\hline
\end{tabular}

\section{NUT BEARING TREES.}

\begin{tabular}{|c|c|c|c|c|c|c|c|}
\hline BUTTERNUT . . . . . . . . . . & & $\begin{array}{l}\text { Each } \\
\$ 1.00\end{array}$ & $\begin{array}{r}\text { Per } 10 \\
\$ 9.00\end{array}$ & HICKORY, Shellbark............ 4 to & $5 \_\mathrm{ft}$. & 1.00 & 9.00 \\
\hline GHESTNUT, American Sweet...... 5 to & $6 \mathrm{ft}$. & 65 & 6.00 & $\operatorname{PEGAN} \ldots \ldots \ldots \ldots \ldots \ldots \ldots \ldots \ldots \ldots \ldots \ldots$ & $3 \mathrm{ft}$. & 1.25 & 11.00 \\
\hline GHESTNUT, Japan or Giant. . & $3 \mathrm{ft}$. & 75 & 7.00 & WALNUT, English........... $11 / 2$ to & $2 \mathrm{ft}$. & 1.50 & 14.00 \\
\hline FILBERT, English... & $4 \mathrm{ft}$. & 45 & 4.00 & WALNUT, Black.... & $8 \mathrm{ft}$. & 75 & 6.50 \\
\hline
\end{tabular}




\section{Ornamental Flowering Shrubs}

ALTHEA (Rose of Sharon). The Altheas are among the mostvaluable of our hardy Shrubs on account of their late season of blooming, which is from August to October a period during which but few shrubs or trees are in flower. They are also extensively used as hedge plants, for which they are admirably adapted.

ALTHEA BOULE-DE-FEU, deep fiery red.....

Each

Doz.

ALTHEA JEANNE D'ARC, double white.....

ALTHEA MEEHANI, beautifully variegated foliage with satiny lavender colored flowers, single fully open and free blooming....

ALTHEA PUPUREA, large single purple......

ALTHEA TOTUS ALBUS, single pure white...

ALTHEA VARIEGATED LEAVES, leaves conspicuously margined creamy white, flowers double purple..............

ALTHEA DOUBLE ROSE, DOUBLE WHITE AND DOUBLE PURPLE.........

BERBERIS PURPUREA (Purple leaved Barberry), an interesting shrub growing 3 to 5 feet high with violet purple foliage and fruit; very effective in groups and masses, or planted by itself, Small plants..................

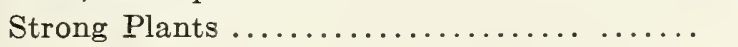

BERBERRY THUNBERGI-A beautiful Japan variety of dwarf habit. Small foliage, assuming the most varied and beautiful tints of ing the most varied and beautiful tints of
coloring in the autumn; very desirable for grouping and a grand hedge plant.........

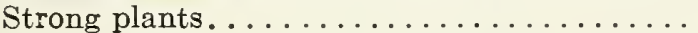

CALYCANTHUS FLORIDUS (Sweet-Scented Shrub).-Flowers fragrant, like strawberries; double and of a chocolate color. ...............

DOGWOOD-(White Flowering).-The flowers produced in spring before the leaves appear, are from 3 to $3 \frac{1}{2}$ inches in diameter, white and very showy. They begin to appear as the and very showy. They begin to appear as the Magnolia flowers are fading, and are invaluable grayish green, glossy and handsome, and in the autumn turns to a deep red; one of the most showy flowering trees.............\$1.00

DOGWOOD (Red Flowering).-A rare variety, similar to the common type except in color of the flowers, which are rich rosy-red. The two varieties make a fine contrast

DOGWOOD (Red Twigged).-A strong growing bush, with crimson-colored branches, especially attractive in winter............... 1.00

DEUTZIA GRACILIS, a dwarf bush, covered with spikes of pure white flowers in early

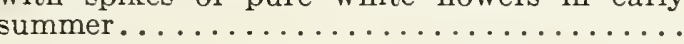

DEUTZIA LEMOINEII-Flowers pure white, borne on stout branches, which are of upright growth. Habit dwarf and free flowering. A decided acquisition.................. Extra strong plants..............

EUONYMUS EUROPAEUS (Burning Bush).-A conspicuous shrub, in the autumn and winter when loaded with scarlet seed pods, from which the orange-colored berries hang on slender threads, 3 feet..................... Extra strong plants.
FORSYTHIA FORTUNEI (Golden Bell) - Of upright growth, deep green foliage and bright Each

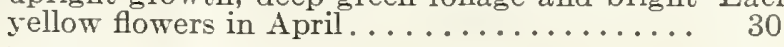

Extra strong plants................ 50

FORSYTHIA VIRIDISSIMA (Golden Bell)Deep green; flowers bright yellow, a fine hardy shrub and one of the earliest to flower in spring.

Extra strong plants.

FRINGE, PURPLE OR SMOKE TREE (Rhus Cotinus)-Has very curious bloom, which when covered with dew resembles a cloud of smoke

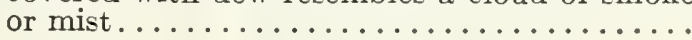

HYDRANGEA PANICULATA GRANDIFLORA. This is the finest shrub in cultivation, and endures heat and cold extremely well. The flowers, which are borne in dense pyramidal panicles in the greatest profusion, are white when they first open, but gradually change to rose and remain in good condition for weeks

Extra strong plants..................

HYDRANGEA PANIGULATA GRANDIFLORA

\section{Standard or Tree Shaped.}

These are fine specimen plants, four and five years old, trained to tree shape with about three feet of straight stem and nicely shaped heads, should bloom profusely the first year. .

Extra strong plants................. 1.25

LILAC COMMON (Syringa Vulgaris)-The common purple species, and one of the best, 3 feet

LILAC COMMON WHITE (S Vulgaris alba).Flowers pure white; very fragrant, 2 feet....

SYRINGA OR MOGK ORANGE.-A well known shrub, with pure white, highly scented flowers.

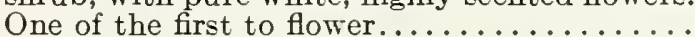

Extra strong plants.................

PYRUS JAPONICA (Japan Quince).-Blooms in early spring; flowers dazzling scarlet. Makes an excellent hedge, 3 feet..............

SNOWBALL OR HIGH BUSH CRANBERRY (Opulis).- Handsome and dense foliage; flowers white, followed by brilliant scarlet edible berries. which hang until late in the winter..

SNOWBALL $(\operatorname{Japan}) \ldots \ldots \ldots \ldots \ldots \ldots$

SPIREA VAN HOUTTII.-The grandest of all the Spireas; it is a beautiful ornament for the lawn at any season, but when in flower it is a complete fountain of white bloom. Clusters of 20 to 30 flat white florets make up the racemes, to 30 these clusters are set close along the and these clusters are set close along the
drooping stems. Perfectly hardy and an early bloomer. Strong plants.............

WEIGELIA EVA RATHKE-A charming variety, flowers brilliant crimson, a beautiful, distinct

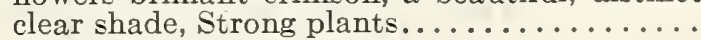

WEIGELIA ROSEA NANA VARIEGATALeaves beautiful margined creamy white; flowers pink. It is a dwarf grower, and adapted to small lawns or gardens, 3 feet. Strong

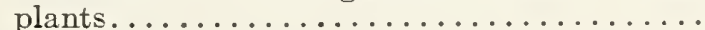




\section{Climbing and Trailing Plants}

\section{AMPELOPSIS.}

VEITCHII-Japan Creeper. Boston Ivy. A rapid growing climber which clings to walls, fences, trees, stumps, etc., with great tenacity. The leaves overlap one another, forming a dense sheet of green in summer, which changes to crimson scarlet in autumn. Strong
2 year old each $75 \mathrm{c}, 10$ for $\$ 6.00$.

\section{ARISTOLOCHIA.}

SIPHO. (Dutchman's Pipe)-A most beautiful climber of rapid growth, with"magnificent light green foliage. Has curious pipeshaped yellowish brown flowers which are very unique and ornamental. Strong plants, each $\$ 1.50,10$ for $\$ 14.00$. 2 year old plants, each $75 \mathrm{c}, 10$ for $\$ 7.00$.
BIGNONIA. TRUMPET VINE........ A hardy climber, of loose trailing habit
of pinkish salmon color. Each 50c.

\section{GELASTRUS.}

SCANDENS (Climbing Bitter Sweet)-A native climbing or twining plant, with fine, large leaves, yellow flower and clusters of orange-capsuled fruit in the autumn. It grows 10 to 12 feet in a season. Each 50c.

\section{CLEMATIS.}

Among the most popular of hardy perennials and not exceeded in beauty and effectiveness by any other class of climbers. They are excellent as a screen for fences, pillars, or trailing on walls or arbors, or on verandas. Very effective in masses of rock work and some are valuable for cultivation in pots. Clematis do best in deep, rich sandy, loamy soil, well mulched with manure, and the finest results are ubtainaed in partial shade, where there is a liberal supply of water given at the roots.

NAMED SORTS-These include Jackmanni (large violet purple), Henryii (large creamy white), Madam Edw. Andre (large bright velvety red). Strong plants each $75 \mathrm{c}$.

COCGINEA-Bell-shaped flowers of bright coral red color. While it is:a smallivariety, is very effective and blooms from June to fall. Each $75 \mathrm{c}$

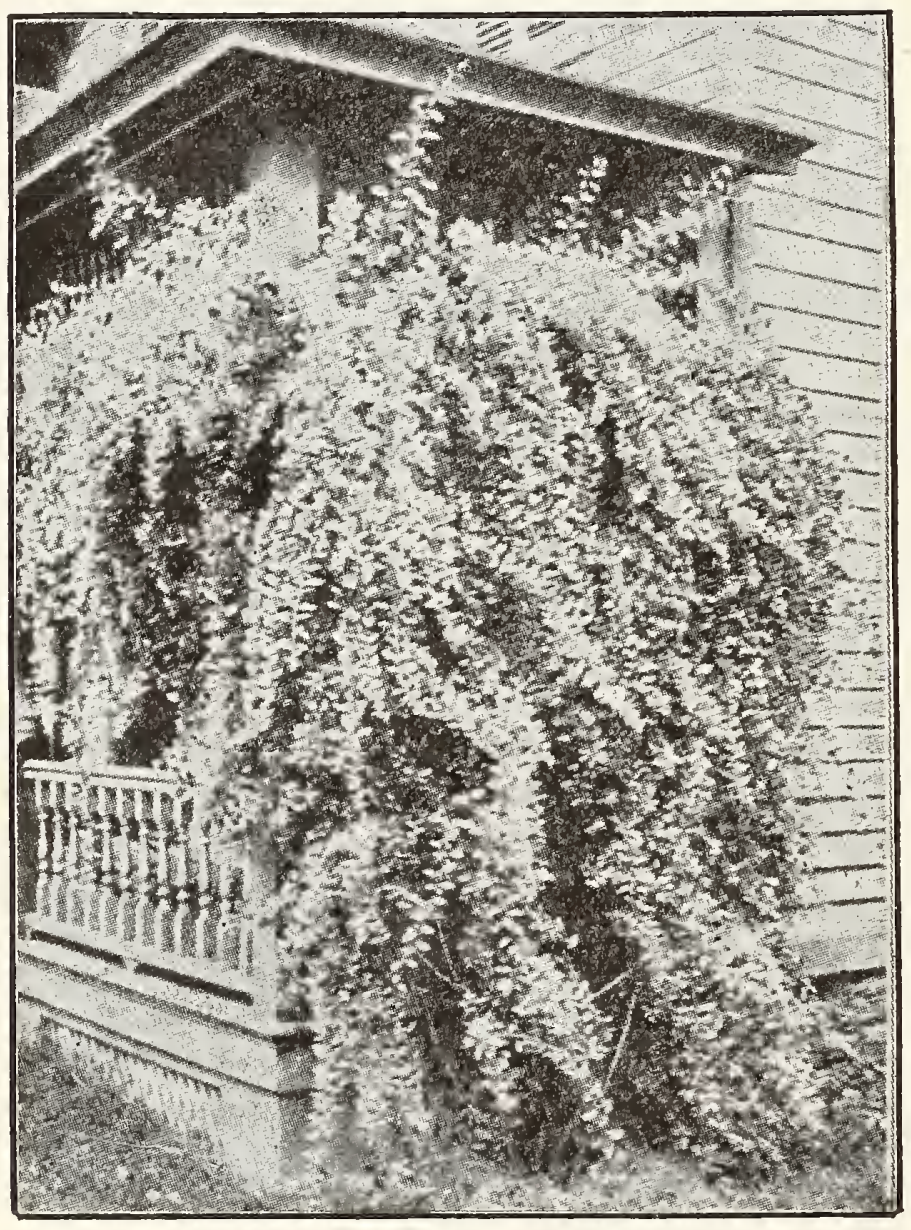

CLEMATIS PANICULATA

PANICULATA-A rapid luxuriant growing sort, bearing immense clusters of small double white flowers in greatest profusion in late summer. It is sweet scented and most desirable for verandas, fences, treillises, and grows from 20 to $30 \mathrm{ft}$. in a single season. Should be cut back to the ground each year. Each $50 \mathrm{c}$.

\section{HONEYSUCKLE.}

Monthly Fragrant-Blooms all summer. Red and yellow very fragrant flowers. Each $40 \mathrm{c}, 10$ for $\$ \mathbf{\$ 3 . 0 0}$.

Japan Golden Leaved-A handsome and very desirable sort with beautifully netted and variegated foliage. Each 45c, 10 for $\$ 3.75$.

Scarlet Trumpet-A strong rapid grower which produces scarlet flowers not sweet scented. Each $50 \mathrm{c}, 10$ for $\$ 4.00$.

HALL'S JAPAN (Halleana)-A strong, vigorous, almost
evergreen sort. Pure white flowers changing to yellow, very fragrant. Blooms abundantly from July to December, holds its leaves until January. Each 40 c, 10 for $\$ 3.00$.

\section{IVY.}

ENGLISH-A well known sort which is used for covering walls or planting in cemeteries, especially in the shade. Each 35c 10 for $\$ 3.00$.

\section{KUDZU VINE. Pueraria Thunbergiana or Jack and the Bean Stalk Vine.}

The most remarkable climber extant. In rich soil will grow 70 feet in one season. It starts into growth slowly, but after 3 or 4 weeks grows almost so rapidly as to be beyond belief. Leaves are of the shape of lima beans, dark green, soft and woloy, fine for porches, arbors, old trees, etc., Strong plants, each 30c, 10 for
2.50.

\section{MATRIMONY VINE-Lycium.}

A well known hardy fast growing vine. It is very handsome when covered with scarlet foliage in the autumn. Used as a trailer especially under trees or on terraces, or any kind of a steep slope, as its roots hold the soil in place. Strong plants, each 40c, 10 for $\$ 3.50$.

\section{SILK VINE-Periploca.}

A rapid-growing beautiful climber. Will twine around a tree or other support to the height of 30 to $40 \mathrm{ft}$. Has beautiful glossy foliage and purple brown clusters of flowers, borne in the axil of the leaf. Each, 60c, 10 for $\$ 5.00$.

WISTARIA.

CHINESE PURPLE (Sinensis)-An elegant and rapid growing climber, attaining a height of 20 feet in a season. Has hundreds of long, pendulous clusters of sweet scented pale blue flowers in May and June and in autumn. Strong 2 yr. plants each, 50c; 10 for $\$ 4.00$.

CHINESE WHITE-Similar to above. Pure white flowers beautiful. Each 60c, 10 for \$5.00.

\section{ORNAMENTAL GRASSES.}

PRICE ALL VARIETIES, 30c each; 10 for $\$ 2.50$.

ERIANTHUS RAVENNAE (Plume Grass)-Grows six to eight feet high and produces handsome plumes in fall.

EULALIA GRACILLIMA-(Japan Rush)-The most beautiful of all the Eulalias, with narrow, reful foliage, entirely green without variegation, except that the mid-rib is of a silver sheen. Perfectly hardy.

EULALIA JAPONICA VARIEGATA-Leaves striped white and green longitudinally.

EULALIA ZEBRINA (Zebra Grass)-A peculiar variegated grass, growing six feet high. The variegation is unlike that of any other plant, being across the leaf in regular bands, dark green and light yellow alternating.

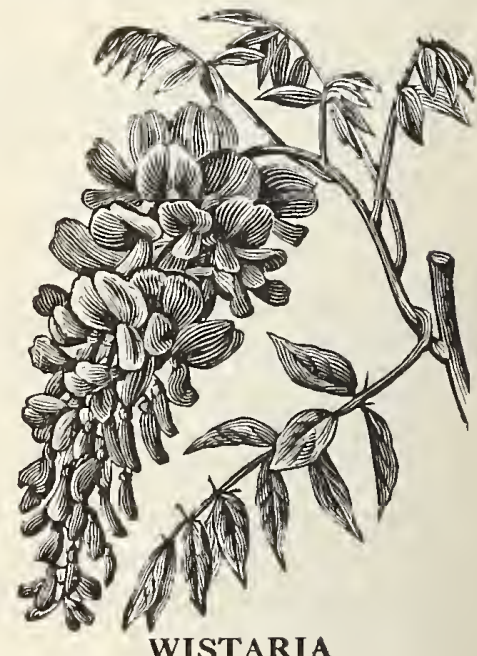




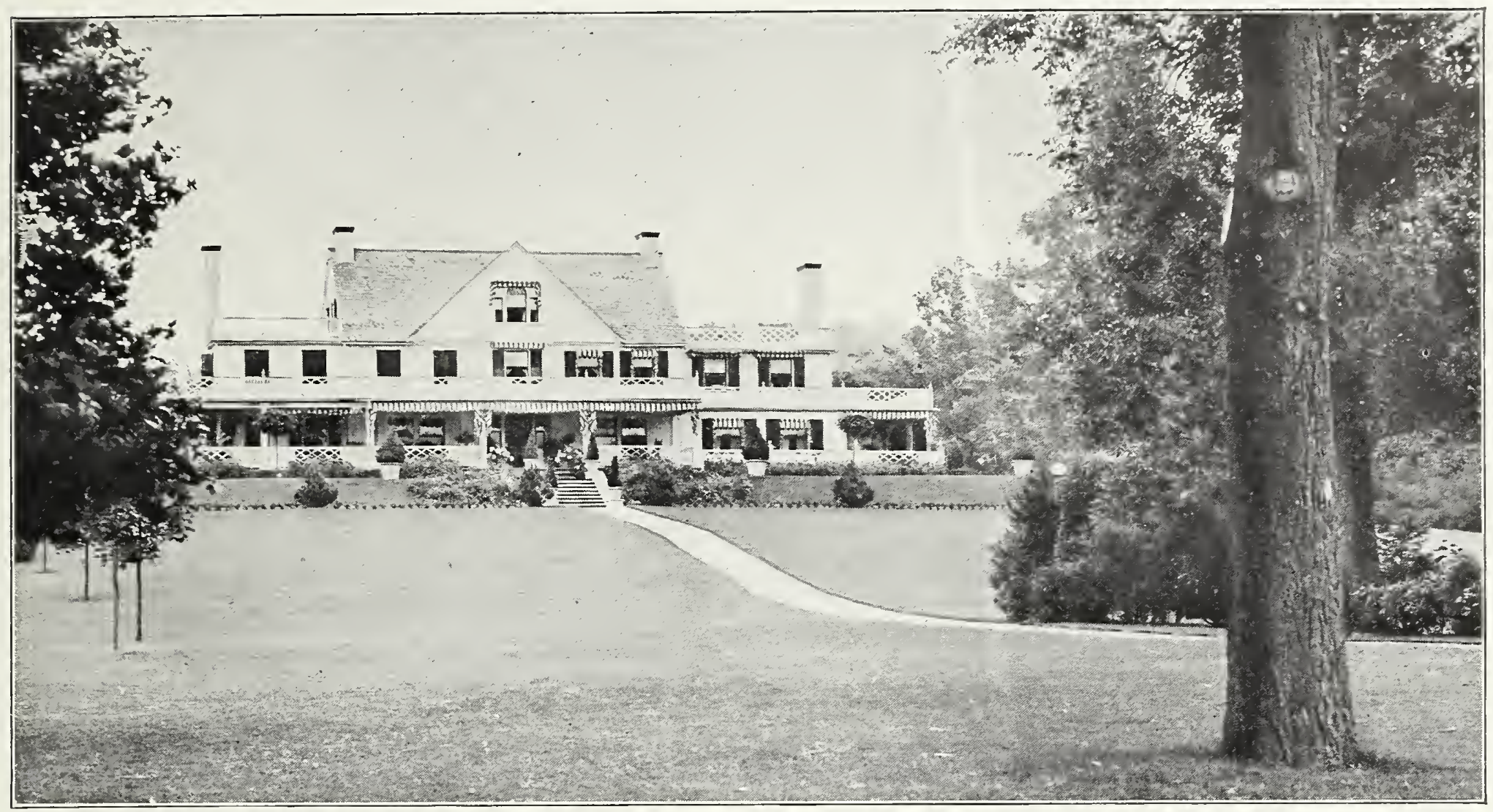

\title{
The J. Chas. McCullough Seed Co.'s "EMERALD" LAWN GRASS SEED
}

\author{
PRICES 1 PT., 15c.; $1 / 2$ LB., 20c; 1 QT., 25c; 1 LB., 35c.;
}

\section{"EMERALD" LAWN GRASS SEED PRODUCES 'THE FINEST SHORT GREEN VELVETY LASTING TURF 6 TO 8 WEEKS FROM SOWING. UNDOUBTEDLY THE BEST OF ALL LAWN SEED FOR VARIED SOILS AND LOGATIONS BOTH FOR LARGE OR SMALL AREAS.}

EMERALD LAWN GRASS SEED is superior to Kentucky Blue Grass or to any other mixture for this section. We have for 40 years made a study of lawns and their care and know from practical experience that no matter what the price or what the claims, J. C. McC. Seed Co.'s EMERALD will give better results, last longer and is undoubtedly the best lawn grass to be obtained.

EMERALD LAWN GRASS SEED is recommended for general lawn purposes, Parks, Cemeteries, Fair Greens, Bowling Greens, Tennis Courts (Sod), Athletic Fields, in fact, anywhere where fine velvety turf is wanted that will withstand hard wear.

\section{QUANTITIES.}

FOR NEW LAWNS-1 qt. sows $200 \mathrm{sq}$. ft. (10 by 20). 1 lb. sows $250 \mathrm{sq}$. ft. (12 by 20). An acre requires 5 to 6 bushels ( 80 to $100 \mathrm{lbs}$.)

FOR OLD LAWNS-It will take about half as much seed as for a new lawn, depending on how thick a stand of grass there is, usually requiring 2 to 3 bushels per acre for renovating.

\section{MAKING LAWNS.}

PREPARATION - The soil should be deeply spaded or plowed, thoroughly pulverized and raked fine and smooth, removing all roots, stones, clods, trash, etc. If not properly graded it should be done now, and allow for water to drain off and not stand in pools. If the lawn is made of clay from recent excavations, it should be covered with 3 or 4 inches of good rich garden soil before the seed is sown.

FERTILIZERS - Pulverized Sheep Manure is thoroughly satisfactory for lawns. Unless stable manure is well decomposed it contains too many weeds, and Sheep Manure is preferable. Quantities required depend on the richness of the soil. If sheep manure is used, 5 to $10 \mathrm{lbs}$. to $200 \mathrm{sq}$. ft., and if ground is not rich, 1 ton per acre is not too much. The Fertilizer should be worked into the soil at the time the seed is raked in.

SOWING - Seed can be sown either in the spring from February to May or in the fall from August to Or.tober. Quantities are given above. It should be pilt on as evenly as possible and half had better be sown one way, then crossing, sowing the other half at right angles. Covering can be done with a smoothing harrow (if in large areas) or with a hand rake (if in small plots) and rolling with a heavy roller will be decidedly beneficial.

CARE OF LAWNS-All lawns should be cut regularly with a lawn mower. This can commence in the early summer when the grass is about 3 inches high and should be done regularly every week and continue until Fall. The grass however should be allowed to attain a fair height for growing through the winter. Watering in excessively dry weather is beneficial, but too much watering is extremely harmful. A good soaking once a week is sufficient for any lawn as constant sprinkling every day will cause the grass to be burned out by the hot sun.

RENOVATING - If the grass is thin it is not necessary in most cases to plow up the entire lawn and reseed, though if it is choked with weeds and there is very little grass left it is decidedly preferable to plow up or spade up entire lawn and seed over. Unless this is the case, however, raking over roughly with a sharp tooth rake and sowing more seed, will improve the lawn wonderfully. Grass usually dies out from lack of plant food, hence it is a good plan to apply sheep manure at the rate of 400 to $600 \mathrm{lbs}$. per acre, latter part of September or in March. 


\title{
LAWN GLEANER AND SWEEPER (PENNSYLVANIA)
}

Cleans lawns of leaves, trash, clippings, etc., faster and better than four men can do it with rakes, etc. It also straightens up the grass and trailing plants so that they can be cut with a mower. Will handle the heaviest fall of leaves easily. The machine is 24 inches wide. Made in a substantial manner, combining lightness with strength and durability. Guaranteed to do satisfactory work.

Price $\$ 20.00$.

RAKES-Steel Garden, 10 tooth

RAKES-Steel Garden, 12 tooth

RAKES-Steel Garden, 16 tooth

RAKES-Lawn, Wire 30 tooth

RAKES-Lawn, Wooden 26 tooth.

Each
$\$ \quad .90$
1.00
1.25
.90
.65

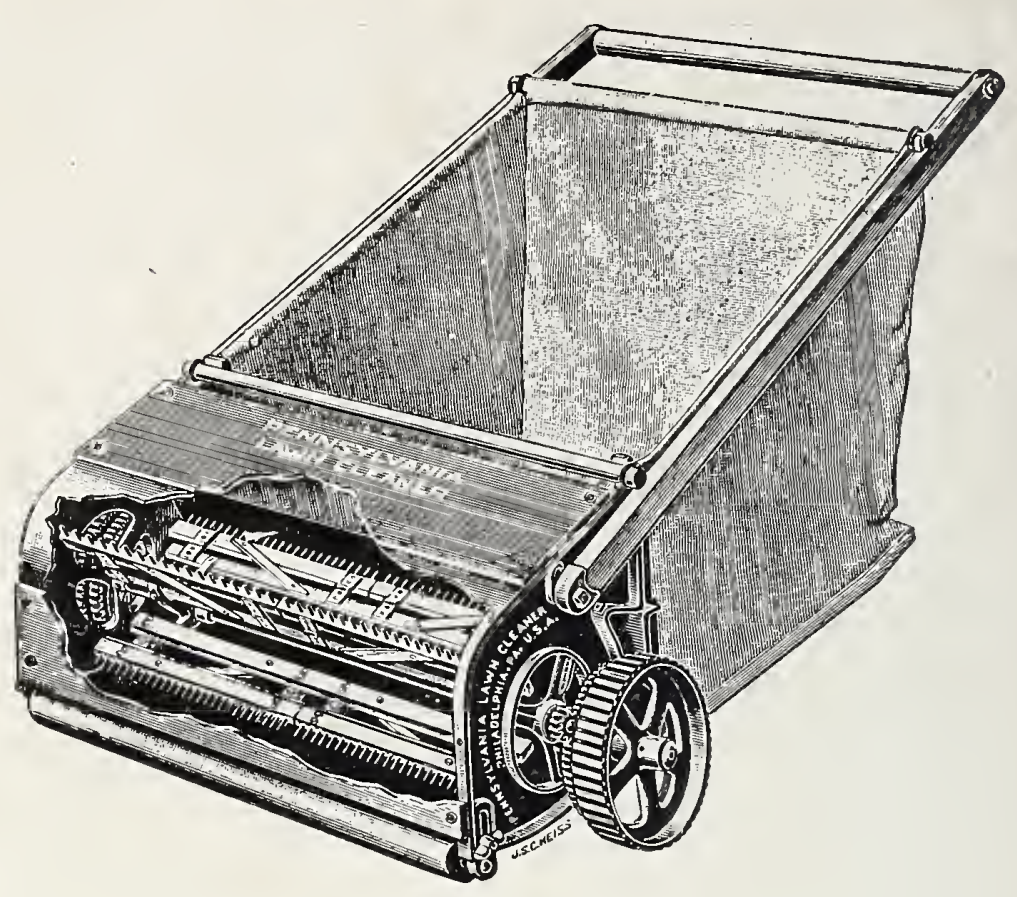

AMERIGAN PLANT TUBS.
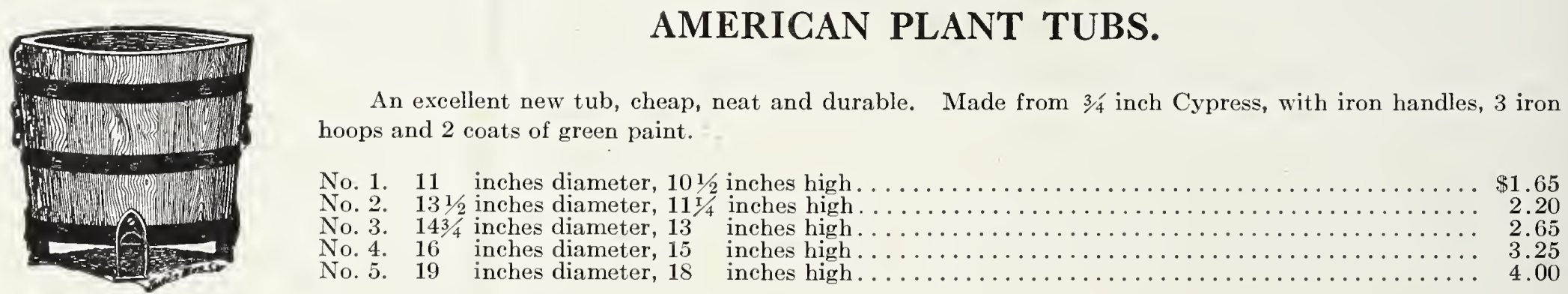

\section{SGALEGIDE (Pratts)}

Apply when trees are dormant.-A preparation of micible oils for San Jose and other scale and insects. It mixes with cold water and stays mixed does not form an emulsion. It is not as disagreeable to use as Lime Sulphur. As a Winter spray use a solution 1 part Scalecide to 15 to 20 parts of water when trees are dormant. For Summer spray, 1 part Scalecide to 25 to 30 parts of water. Prices, 1 gal., \$1.45; 5 gal., \$6.45; 30 gal., \$27.00; barrel (50 gal.), $\$ 39.50$.

\section{MISGELLANEOUS FARM SEEDS}

Red Top Orchard Grass, Rye Grass, Timothy, Glover, Alfalfa, Wheat, Rye, Oats, Etc. Prices on Application.

We are General Agents for

BUCKEYE INCUBATORS and STANDARD GOLONY BROODERS

\author{
Special Catalogue Mailed on Application.
}

